\title{
Far Western, Western, and Eastern Lapita: A Re-Evaluation
}

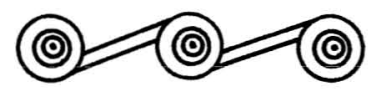

\section{GLENN R. SUMMERHAYES}

Although NeAR OCEANia has been populated for over 35,000 years, the settlement of the islands east of the main Solomon Island chain, known as Remote Oceania, occurred about 3000 years ago. The archaeological signature of these colonizers is a distinctive type of pottery called Lapita. It is found from Aitape on the north coast of New Guinea in the west to Samoa in the east in contexts dated between c. 3350 and 2350 B.P.

Archaeologists working in the region today are attempting to understand the nature of the societies that produced and used Lapita pottery and the nature of the interactions among these societies. Similarities in pottery decoration, in particular dentate stamped motifs in association with radiocarbon estimates, have been used by archaeologists to identify the spread of settlement over the Pacific and also the presence of inter-island interaction and exchange among geographically separated areas. On the basis of such stylistic similarities and to a lesser extent on the nature of inter-island exchange (Green 1978:3), these areas have been grouped into a number of Lapita provinces (see Fig. 1). Terms such as "stylistic provinces," "interaction spheres," and "exchange networks" are used, sometimes interchangeably, in the literature. For instance, the terms "Far Western Lapita" (or "Early Western Lapita" as Spriggs [1995:116] prefers), "Western Lapita," "Southern Lapita," and "Eastern Lapita" have been given to "geographical subregions of Lapita" or "provinces" (Kirch 1997:58, 71). Yet they are also seen as "sub-styles" of Lapita, which have both geographical and chronological significance (Spriggs 1995:116). Regions thus delimited have also been used to describe exchange networks or different interaction spheres.

As outlined below, these provinces are important heuristic devices in modeling the process of colonization and the nature of group interactions. It should be noted that in other regions, such as Europe or America, archaeologists have recognized that migrationist models do not adequately explain the spatial distribution of materials or the spread of agriculture. This has led them to examine other explanatory mechanisms. Yet in the Pacific, migrationist models have "explanatory power" (Spriggs 1989) as here we are dealing with a rapid colonization movement into unoccupied Remote Oceania. Thus in developing these models 


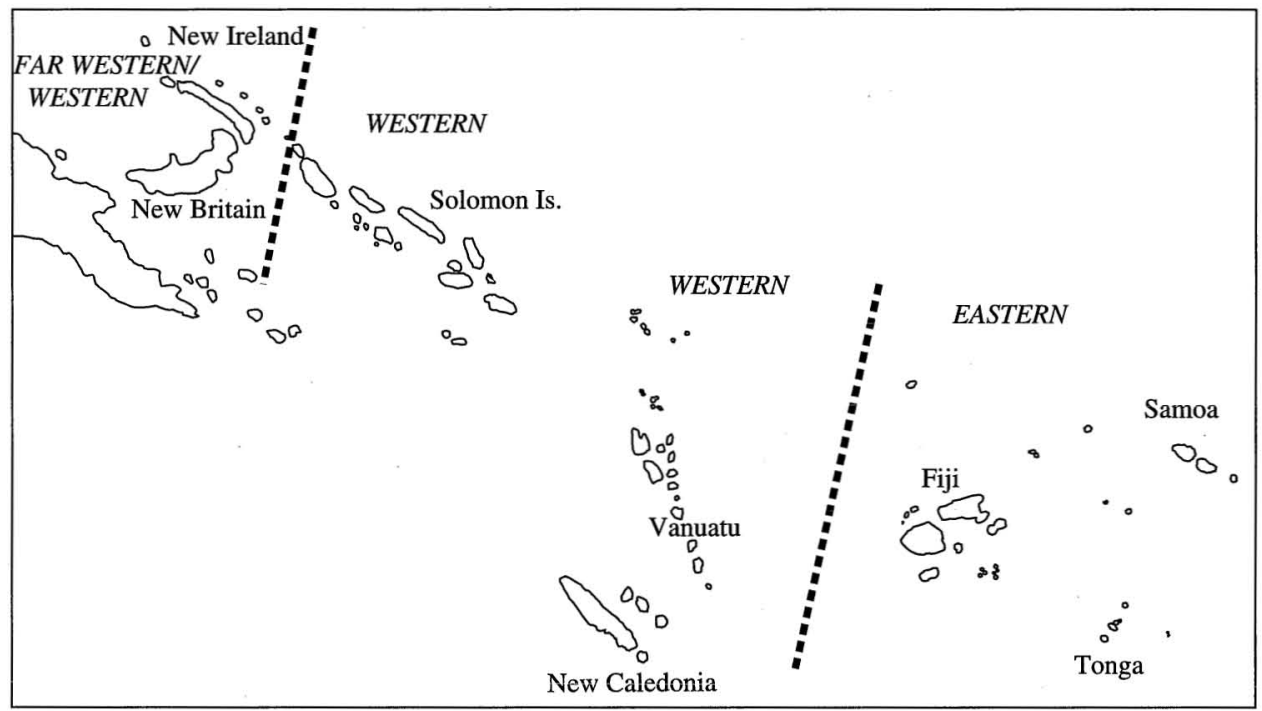

Fig. 1. Lapita provinces.

of colonization and interaction in Remote Oceania, language, material culture, and subsistence have been grouped together. Where this grouping is not so straightforward is in Near Oceania, which has been occupied for over 35,000 years.

A major problem in assessing the changing nature of Lapita interaction within Near Oceania is the lack of sites showing stylistic change over time within the Bismarck Archipelago. The definition of provinces was based on single-phase sites showing little change within an assemblage. An attempt is made here to redress this problem by presenting the results of a stylistic analysis on pottery assemblages with long sequences from West New Britain, and to critically assess whether they conform to the defined sequences already established for the region. A comparison is made with assemblages from Western Melanesia in an attempt to review the processes of interaction among Lapita communities based on ceramics.

The paper is structured into four parts. The first reviews the models for the Lapita colonization of the western Pacific, the definition of Lapita provinces, and their relationship to processes of interaction. It discusses how an analysis of longer pottery sequences in the Bismarck Archipelago can assess the insularity of Lapita provinces. The second part sets out the assemblages under study, while the third presents the results of the stylistic analysis. This is followed by a discussion of the results and a re-assessment of the regionalization of the western Pacific.

\section{MODELS OF COLONIZATION AND INTERACTION}

There are three main models for the Lapita colonization of Remote Oceania.

\section{The Fast Train}

The first involves a movement of Austronesian-speaking people out of Southeast Asia and into Remote Oceania, passing through the Bismarck Archipelago, carry- 
ing with them their material cultural repertoire (the Lapita Cultural Complex). Based on early radiocarbon estimates, the initial occupation of the Bismarcks was seen as predating occupation in Fiji, $3000 \mathrm{~km}$ to the east, by a century at the most (Kirch et al. 1987). This led proponents of this model to interpret the spread of Lapita colonization as archaeologically instantaneous (see Kirch and Hunt 1988; Kirch et al. 1987) thus accounting for the similarity in material culture over a vast region. This model considers domestication of animals, people, the Austronesian languages of the Pacific, and many elements of the material cultural kit to be derived from Southeast Asia. In this model any subsequent change in the pottery style is due to subsequent isolation of populations. For instance, when Lapita colonists moved east, it is argued that they began to fragment into smaller regional entities with local patterns of communication and interaction between settlements. When colonizing populations settled in Fiji, Tonga, and Samoa, it was supposed that the major sea gap separating them from Vanuatu became an effective barrier making two-way voyaging infrequent (Green 1974a, 1979). Settlements to the west of this major sea gap were defined as Western Lapita and those to the east from Fiji, Tonga, and Samoa were called Eastern Lapita (see Green 1976, 1978, 1979). Table 1 shows which areas categorize Western and Eastern Lapita.

Isolation (or processes that derive thereof) is seen as the key reason for the development of an Eastern and Western style province. Isolation equates with less communication, as seen in the lessening of shared motifs between these two areas (Green 1978:11). Kirch $(1988 b: 106)$ also uses and expands upon this model of two interaction spheres or networks. Like Green he sees the water barrier between east and west being crossed "at least once (and perhaps several times)," thus explaining the sharing of an early set of decorative motifs, with any later differences resulting from "subsequent isolation and local stylistic divergence" (Kirch $1988 b: 105)$.

The Western and Eastern Lapita styles were originally defined on both vessel form and decoration (Green 1978:7, 1974a). The distribution of dentate motifs is significant here. Based on the previous work of Donovan (1973), Mead et al. (1975), his students, and indeed his own work, Green (1990:36) compiled a total of 122 motifs in assemblages from Watom in the west to Tonga in the east, and from a subset of these made comparisons between those assemblages.

There are three reasons why this analysis is a cornerstone for interpreting Oceanic prehistory. First was the recognition of a "substantial corpus of early motifs spread from Watom to Samoa" (Green 1979:40). Secondly, despite the early widespread motifs, Green identified "separate style areas" (Green 1979:43; Pawley and Green 1973:11) —an Eastern and Western Lapita component based on a distinction among their motifs (Green 1978:9). He also noticed a distance decay in the Lapita design system the further one proceeds east "from the rather ornate curvilinear and fairly elaborate rectilinear design patterns of the western Lapita to the more simplified and generally rectilinear forms of the eastern Lapita" (Green 1979:42). Kirch (1997:157) sees this distance decay as most evident in the Eastern Lapita. Third, Green identified temporal change in decoration and vessel shape, with the pottery undergoing different changes in the two style areas. In the west, the Reef/Santa Cruz pottery assemblage showed decorative decay over time (SZ-8; RL-2; RL-6) although the variety in vessel shape (shouldered jars, bowls, flat-bottomed dishes, etc.) stayed the same (Green 1978:13, 1979:43). In the east, on the other hand, Green $(1978: 13,1979: 44)$ noted that the elabo- 
Table i. Fast Train Model. Distribution of Two Geographically Separated Style Provinces

\begin{tabular}{lccc}
\hline & & $\begin{array}{c}\text { SOLOMONS, VANUATU, } \\
\text { NISMARCK ARCHIPELAGO }\end{array}$ & FIJI, TONGA, SAMOA \\
\hline Eastern & $\times$ & $\times$ & $\times$ \\
Western & $\times$ & & \\
\hline
\end{tabular}

Note. Settlement is seen as archaeologically instantaneous.

rate vessel forms disappear and only simple bowls and globular-shaped pots with little or no decoration remain (see also Parker 1981:124). In between, Green noted that incising increases and there are fewer vessel forms from the sites on Malo in Vanuatu.

In the east Green defines a transition from his Early Eastern Lapita to Late Eastern Lapita to Polynesian plain ware based on "differences in vessel shape and by the style and frequency of decoration” (Green 1974a:251, fig. 90; 1979:42, fig. 2.9). Since his initial definition, excavations on Niuatoputapu (Kirch 1988a), Uvea and Futuna (Kirch 1976, 1981), Lakeba (Best 1984), Naigani (Best 1984; Kay 1984), Ha'apai Islands (Burley 1998; Burley et al. 1999; Shutler et al. 1994), and Samoa (Jennings et al. 1976; Jennings and Holmer 1980) have reinforced this distinction.

The two models discussed below are not in disagreement with the nature of interaction of Lapita communities once they left the Bismarck Archipelago, and the subsequent isolation of communities as evident by the Western and Eastern Lapita provinces. Where they differ with the "fast train model" is with the role of the Bismarck Archipelago in the development of Lapita societies.

\section{Indigenous Bismarck Archipelago Model}

The second model sees the development of the Lapita Cultural Complex within the Bismarck Archipelago. That is, the colonization of Remote Oceania has its origins in the Bismarck Archipelago, with the Lapita Cultural Complex arising from internal social and economic developments of the previous 35,000 or so years of occupation (Allen 1984; White and Allen 1980). Despite this, people did not live in a vacuum and could have had contacts with the west from which they may have acquired the skills to make pottery, seen in this model as "culturally unaccompanied baggage" (Kennedy 1983:120). As Allen noted (1991:7) "such contacts would have facilitated the flow of materials, technologies and people in both directions."

\section{The Slow Train}

The third model, although seeing the origin of the Lapita Cultural Complex in Southeast Asia (as in model 1), takes into account the possibility that Lapita may have been in the Bismarcks for 300 years before spreading out into Remote Oceania. Roger Green (1991a) has developed a variant of this model that he calls the Triple I model: Intrusion/Innovation/Integration. Intrusion equates with Austronesian speakers coming into the area from Southeast Asia bringing with 
them items of material culture. Innovation equates with new developments within the Bismarck Archipelago, while integration equates with adopting elements of material culture from the area's original inhabitants. Thus people may have paused in the Bismarcks and indeed picked up local elements of material culture on the way (Green 1991a), perhaps learning to adapt "to an area with a complex continental island environment, which possessed a wide range of resources" (Green 1979:45) —a kind of "homeland" (see also Spriggs 1989:608).

Both the second and third models see the Lapita Cultural Complex as developing in the Bismarck Archipelago before colonizing groups left the area for Remote Oceania. Evidence for this was seen in the definition of an earlier stylistic province by Dimitri Anson $(1983,1986)$. Anson added another dimension to the Western style area by adding "Far Western" to the literature. Anson undertook a stylistic analysis of sites within the Bismarck Archipelago and compared them both quantitatively and qualitatively with sites in Remote Oceania. From within the Bismarck Archipelago he compared the decoration of pottery from the Lagenda Plantation collection (FCR/FCS) near Talasea in West New Britain, Malekolon (EAQ) on Ambitle Island, off the southeast coast of New Ireland, Eloaua (ECA) in the St. Matthias Group, and Watom (SAC, SAD) off the northeast end of New Britain. Anson adapted Mead's and Donovan's original motif lists to include their alloforms, i.e., variations of a motif, as separate motifs, thus expanding the motif list to over 500 (Anson 1983:59, 1986:160, 1990:53).

Anson's work on motifs came to two major conclusions. First, on the basis of stylistic similarity among assemblages from Talasea, Eloaua, and Ambitle, he identified a Far Western style particular to the Bismarck Archipelago, which he argued was earlier than the later Western style of Watom, the Reef/Santa Cruz area, Vanuatu, and New Caledonia. Secondly, by looking at the alloform level, he identified that "decoration at any given site and from any given region more strongly resembles that of other sites in the same region than it does the decoration of sites in other regions, irrespective of chronology" (Anson 1986:163). He goes on to say that this is "best explained as the result of gradual changes within each of the widely dispersed regions, and suggests that communication between them was rather less frequent than the Colonizer model would imply" (Anson 1986:163). Table 2 presents the break-up of the three style provinces into an earlier and later period, by geographical area.

The proponents of the indigenous Bismarck and slow train models saw this as evidence that ceramic styles developed within the Bismarck Archipelago prior to

Table 2. Slow Train Model. Distribution of Three Style Provinces

\begin{tabular}{|c|c|c|c|}
\hline & BISMARCK ARCHIPELAGO & $\begin{array}{c}\text { SOLOMONS, VANUAT } \\
\text { NEW CALEDONIA }\end{array}$ & FIJI, TONGA, SAMOA \\
\hline Eastern & & & $x$ \\
\hline Western & $x$ & $x$ & \\
\hline Far Western & $x$ & & \\
\hline
\end{tabular}

Note. The settlement is not seen as archaeologically instantaneous, with Far Western preceding Western assemblages in the Bismarcks. Far Western is geographically exclusive to the Bismarcks. The later Western and Eastern provinces are geographically separated. 
the settlement of Remote Oceania. Some adherents to the "Out of Southeast Asia" model originally argued that this province did not exist and was defined on inadequate sampling (Kirch et al. 1987). The initial spread of Lapita should have resulted, they thought, in a uniform style across western Melanesia with any change in the pottery style the result of the subsequent isolation of these populations. Thus unique motifs in the Bismarcks may "signal little more than local stylistic divergence after the initial Lapita dispersal through eastern Melanesia" (Kirch et al. 1987:126). Kirch has, however, recently redefined Far Western Lapita as a regional term, with both an early and later phase (1997:287).

\section{Discussion}

All three models work on the assumption that the difference between Eastern and Western Lapita is the result of varying degrees of isolation after initial colonization and the beginning of regional social systems (Kirch 1997:70). These style provinces are thus a spatial and temporal phenomenon (Kirch 1997; Spriggs 1995). These changes reflect what Green and Kirch (1997:30) have recently called "communication" boundaries, which they interpret as "the differentiation, both linguistically and culturally, of more localized ethnic identities."

Kirch $(1988 a: 188,246)$ has gone further and subdivided the Eastern Lapita network into two subgroups: a northern group made up of Mulifanua (in Samoa), 'Uvea, and Niuatoputapu (Tonga) on one hand, and the assemblages of Tongatapu (Tonga) and Fijian sites such as Natunuku, Yanuca, and Naigani on the other. With regard to decoration, the northern group shares a simplified set of design elements and motifs. Tikopia and Sigatoka (Fiji) are "more simplified derivatives of the NT-90(Niuatoputapu)/Uvea/Mulifanua complex" (Kirch 1988a:187). Tikopia, however, is unusual as it is within the geographical domain of the Western Lapita (Kirch 1988a:188). Kirch and Yen (1982:337-338) proposed settlement from the east to explain the similarity in Tikopia's pottery with assemblages found in the easterly sites. All motifs found in Tikopia are found in Mulifanua, Niuatoputapu (NT-90), and 'Uvea (Kirch 1988a:189). To explain the presence of Bismarck Archipelago obsidian, Kirch (1988a:189) suggests that "early Tikopian colonists established some intermittent contact with Lapita peoples in the Reef/Santa Cruz islands." The presence of Eastern Lapita pottery on Tikopia is thus explained as the result of isolated interaction from the east. That is, the Eastern Lapita style developed in the east and is particular to the Eastern Lapita province.

Thus all three models agree that the Western and Eastern Lapita provinces become differentially isolated after the initial spread of the Lapita colonizer groups out of the Bismarck Archipelago. However, what happens within each province over time? One of the gaps in Melanesian archaeology is the lack of time depth in assemblages within the Bismarck Archipelago. Anson noted the limited fieldwork undertaken in the Bismarck Archipelago at the time he defined his Far Western Lapita style. He predicted that with further fieldwork, sites would be found with decoration intermediate between Far Western and Western Lapita. He (Anson 1986:164) also called for better-dated sites with larger samples of decoration from the Bismarck Archipelago to test hypotheses concerning colonization strategies in the Pacific. The research presented in this paper attempts to answer Anson's call. 
Table 3. West New Britain Pottery Assemblages Analyzed

\begin{tabular}{lll}
\hline SITE CODE & \multicolumn{1}{c}{ NAME OF SITE } & \multicolumn{1}{c}{ SQUARES SAMPLED } \\
\hline Arawe Islands & & \\
FNY & Paligmete, Pililo Island & TP 1 sq M/N $1-2(2 \times 2 \mathrm{~m})$ \\
FOJ & Apalo, Kumbun Island & TP 2 sq O 1-4 $(4 \times 1 \mathrm{~m})$ \\
FOH & Makekur, Adwe Island & TP 10 sq D/E/F $1-3(3 \times 3 \mathrm{~m})$ \\
FOH & Makekur, Adwe Island & TP 15 sq G $1-2(2 \times 1 \mathrm{~m})$ \\
Other South Coast Sites & & \\
FNT & Kreslo & \\
Talasea Area & & $1 \times 1 \mathrm{~m}$ \\
FEA & Boduna Island & $4 \times 4 \mathrm{~m}$ \\
FSZ & Garua Island & \\
\hline
\end{tabular}

Note. Locations are shown in Figures 3 and 4.

This paper addresses the definition of stylistic areas by focusing on assemblages from one area in the Bismarck Archipelago, West New Britain, to assess the concept of Far Western, Western, and Eastern Lapita styles and the implications derived from them.

\section{ASSEMBLAGES USED IN THIS STUDY}

Assemblages under study were provided by Jim Specht, Chris Gosden, and Robin Torrence (see below) and are listed in Table 3. They cover the major areas where research has been undertaken in West New Britain: Arawe Islands, Kreslo, and Talasea region (see Fig. 2). For detail on sampling assemblages, see Summerhayes $(2000 a)$.

\section{Arawe Islands}

All the major Arawe pottery assemblages are analyzed: FOH, FOJ, and FNY. Within each site test pits that contained the densest concentration of pottery were selected for analysis. For a detailed description of the Arawe sites including depositional history, see Summerhayes (2000a), Gosden (1989, 1990, 1991), and Gosden and Webb (1994). Figure 3 shows the location of Arawe sites.

Site FOH is located on a sand spit, known as Makekur, projecting out from the northern tip of Adwe Island. Site FOJ is a beachfront deposit located in the village of Apalo, on the eastern end of Kumbun Island. Site FNY is on the beach in Paligmete village on the northwest side of Pililo Island. Table 3 presents the test pits and squares from which pottery was drawn for analysis.

Radiocarbon estimates associated with Lapita pottery assemblages range from c. 3250 cal B.P. to 2300 cal B.P. Specht and Gosden (1997, Appendix 1 and 3) provide ${ }^{14} \mathrm{C}$ estimates for $\mathrm{FOH}$ square $\mathrm{G}$, FOJ, and FNY. Two ${ }^{14} \mathrm{C}$ estimates have also been recently obtained from the bottom cultural layer of FOH square D/E/F (ANU 11187, 3140 [2830] 2710 cal в.P.; ANU 11186, 3240 [2910] 2875 cal B.P.). At two standard deviations the calibrated ages are:

1. FOH squares $\mathrm{D} / \mathrm{E} / \mathrm{F}: 3250-2750$ cal B.P.

2. FOH squares $\mathrm{G} / \mathrm{H}: 2930-2340 \mathrm{cal}$ в.P.

3. FOJ: $2960-2350$ cal в.P. 


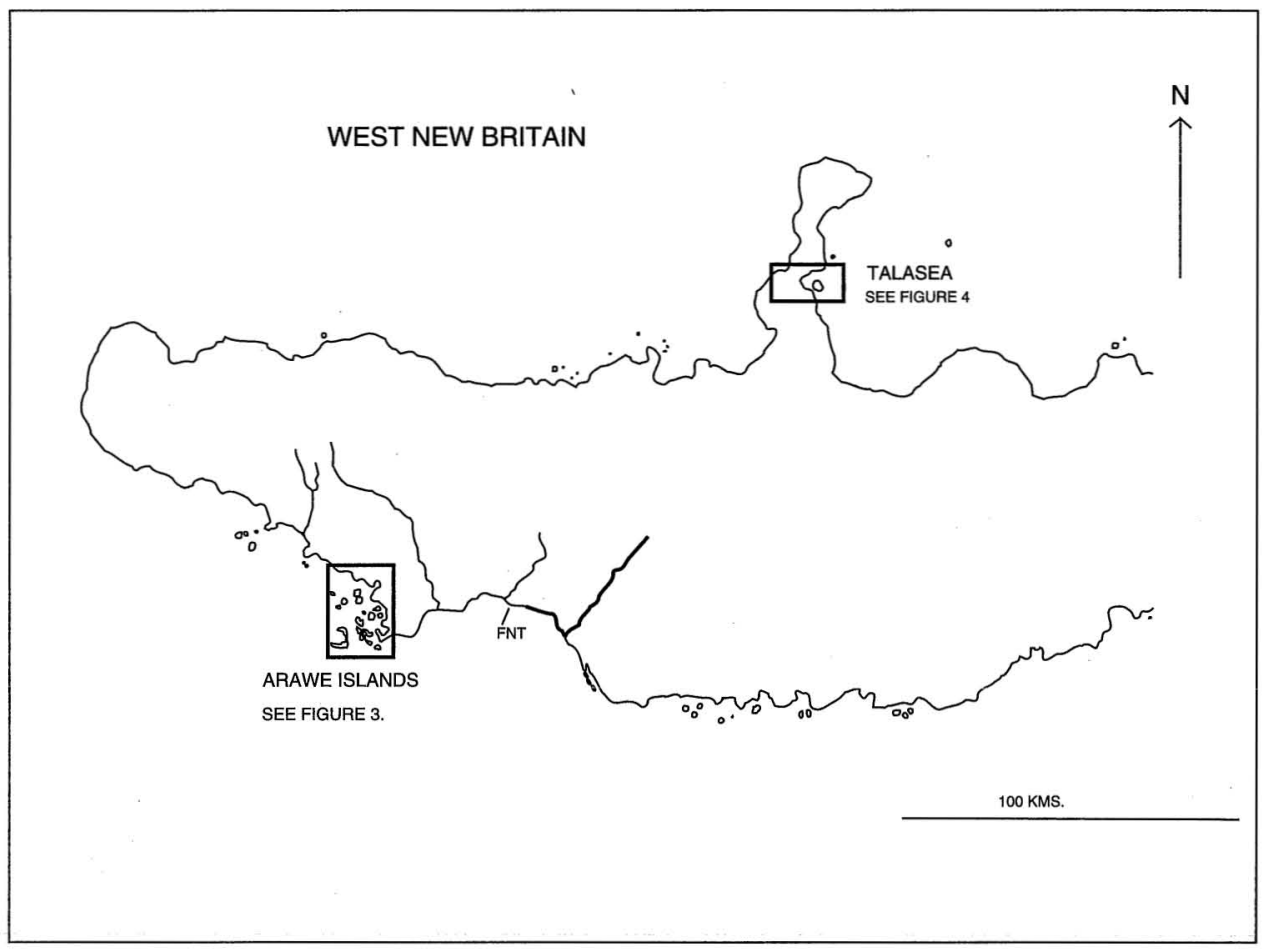

Fig. 2. Archaeological sites on West New Britain.

4. FNY: $2750-2340$ cal B.P. (unreliable estimate; an early Lapita layer which is redeposited).

Although the assemblages from $\mathrm{FOH}$ squares $\mathrm{G} / \mathrm{H}$ and $\mathrm{FOJ}$ are later than $\mathrm{FOH}$ squares $\mathrm{D} / \mathrm{E} / \mathrm{F}$, relating these radiocarbon determinations to changes in the ceramic record is far from satisfactory due to the small number of determinations. Only eight radiocarbon estimates are available in association with Lapita pottery from the assemblages selected (FOH square D/E/F, ANU 11186, ANU 11187, Beta 55323; FOH square G/H, Beta 37561, Beta 54164; FOJ, Beta 29244, Beta 29245; FNY, Beta 27940). Two of these are regarded as unreliable. One Tridacna sample (Beta 55323) from $\mathrm{FOH}$ square $\mathrm{D} / \mathrm{E} / \mathrm{F}$ is reported to have a conventional age of $2800 \pm 70$ B.P. (Specht and Gosden 1997, Appendix 1), although there is now doubt whether it was $\delta 13 \mathrm{c}$ corrected $(+1.0 \% \mathrm{E})$. If a correction needs to be done, the conventional age would become $3230 \pm 70$ в.P., which after calibration (3240 [3039] 2846 cal B.P.) brings it more in line with other determinations from this square. Only a single age estimate is available from Paligmete, FNY, and this comes from a layer (sticky brown clay) that has evidence of disturbance and redeposition (a lens of sterile white sand).

\section{Kreslo}

Kreslo is situated on an intertidal coral platform that lies halfway between Kandrian and the Arawe Islands ( $2 \mathrm{~km}$ east of the Anu River). Scatters of pottery and 


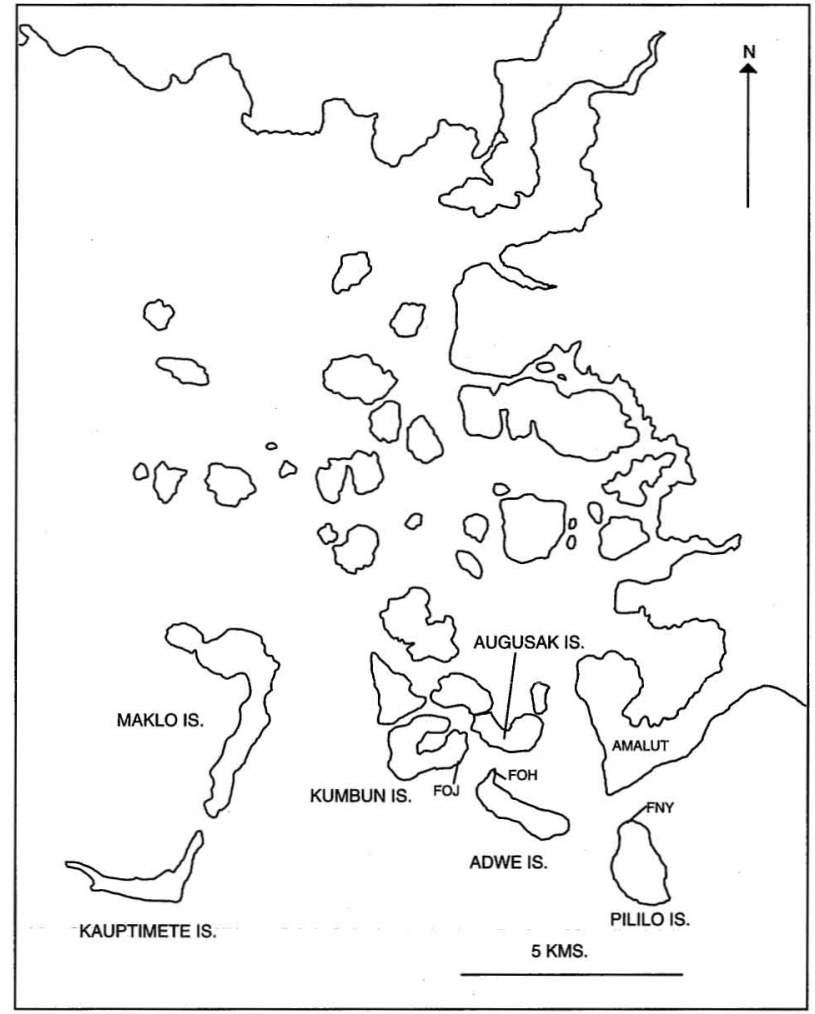

Fig. 3. Archaeological sitesArawe Islands.

obsidian were found beneath the water (FNT). Behind the platform on the landward side, vertical limestone cliffs rise $20-30 \mathrm{~m}$, and an embayment is located to the west of the site. Specht (1991) noted that the reef bifurcates parallel to the coast, with a lagoon created by the outer extension of the reef protecting the Kreslo area from the ocean swell. The scatter of artifacts is $250 \mathrm{~m}$ long, beginning $15 \mathrm{~m}$ further seaward from the high water mark and extending $25 \mathrm{~m}$ towards the passage in the reef (Specht 1991).

\section{Garua Island}

Garua Island is situated near Talasea on the Willaumez Peninsula (Fig. 4). It has two extinct volcanoes associated with the obsidian sources: Baki and Hamilton. FSZ sits on top of a scoria cone $30 \mathrm{~m}$ above sea level overlooking Garua Harbor. The pottery for analysis came from excavations in 1992 and 1993 (Torrence and Webb 1992; Torrence 1993). Two radiocarbon determinations associated with pottery are available from the 1992 field season: 2361 (2328) 2137 cal B.P. (NZA 2851); 2798 (2348) 2192 cal в.P. (NZA 2852) (Torrence pers. comm.).

\section{THE RESULTS}

In order to place the West New Britain pottery assemblages into a regional framework, sherds were analyzed in terms of form, decoration, and fabric. For- 


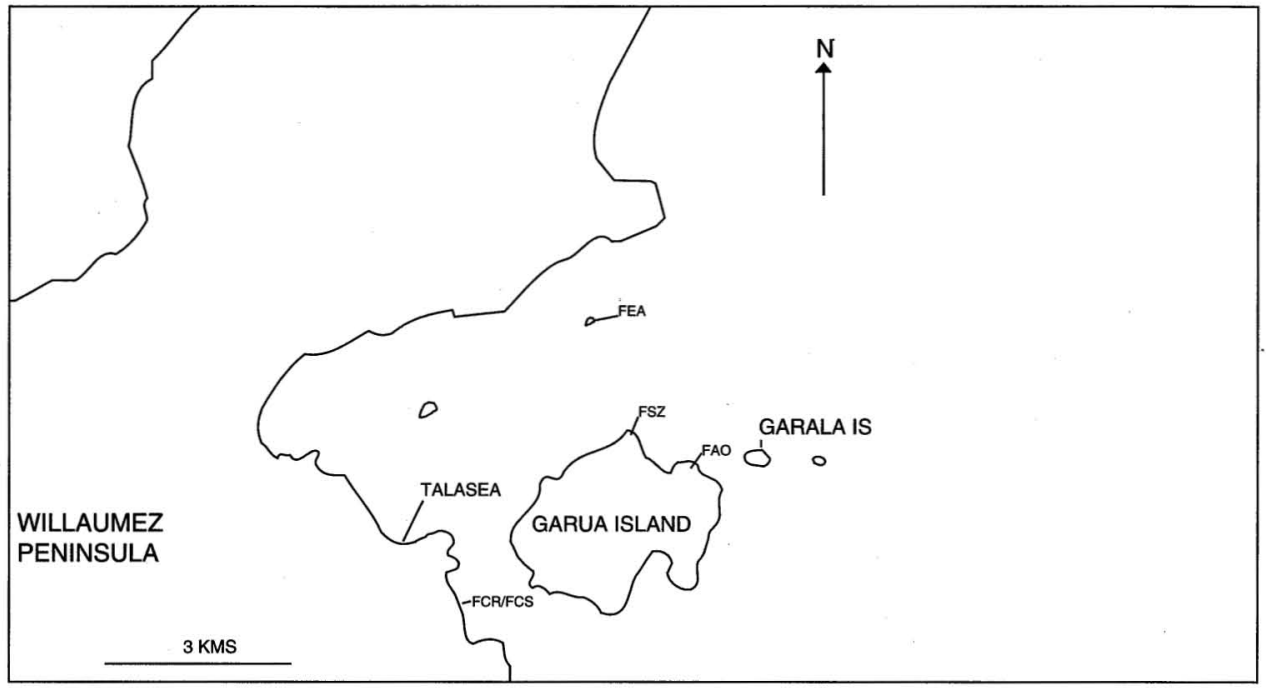

Fig. 4. Archaeological sites in the Talasea District.

tunately, the Arawe assemblages are found in unique preservation contexts, which allow a comprehensive study of vessel shape. The size, particular shape, or decoration of some sherds allowed easy conjoining of sherds. All dentate motifs are recorded using Anson's inventory (Anson 1983, table 12). Motifs not found in Anson's inventory are noted separately. The incidence of motifs is compared with other sites in the western Pacific. A more detailed discussion of the pottery assemblages and analysis can be found in Summerhayes (2000a).

I will now examine the dentate component of the assemblages in terms of the frequency of dentate decoration on sherds and on vessels. This will be followed by an analysis of dentate motifs and comparisons with other pottery assemblages from the western Pacific.

\section{The Dentate Component}

On the basis of both the frequency of dentate decoration and form of dentate vessels, Arawe assemblages separate into two. Within Adwe FOH squares D/E/F and Paligmete FNY, dentate accounts for 66 percent and 61 percent of all decorated sherds respectively, while at Apalo FOJ and Adwe FOH square G, it is only 22 percent and 28 percent, respectively.

In terms of vessel forms with dentate-stamped decoration, the twofold grouping is also applicable. In Paligmete FNY and Adwe FOH squares D/E/F, which have high dentate sherd counts, dentate vessels account for 44 percent and 24 percent of all vessels. This is in contrast to Adwe FOH square G and Apalo FOJ where dentate vessels comprise only 16 percent and 12 percent of the assemblage, respectively.

Dentate decoration found in the assemblages of both Paligmete FNY and Adwe FOH squares D/E/F occur mainly on bowls and stands. This contrasts with Adwe FOH square $\mathrm{G}$ and Apalo FOJ where bowls and stands are proportionally 
Table 4. Number of Motifs per Site

\begin{tabular}{lcc}
\hline SITE & NO. OF ANSON MOTIFS & NO. OF NEW MOTIFS \\
\hline FOH Sq. D, E, and F & 53 & 39 \\
FOH Sq. G & 10 & 2 \\
FNY & 51 & 10 \\
FOJ & 20 & 7 \\
FSZ & 15 & - \\
FNT & 8 & - \\
\hline
\end{tabular}

fewer. Without this dentate vessel component, the differences between sites are diminished, with plain bowls, carinated jars (mostly with lip modification or plain, with some having linear incised or fingernail-impressed decoration), and plain globular pots remaining.

Thus the decrease of dentate as a proportion of decorated ware from Paligmete FNY, Adwe FOH squares D/E/F, to Apalo FOJ and Adwe FOH square G, can be seen in terms of a decrease in bowl and stand vessels - the dropping out of this specialized component. As will be discussed below, this appears to be correlated with a change in dentate motifs from Far Western to Western Lapita styles.

\section{Defining a Regional Character}

To look at the structure of dentate motifs between sites and within vessel forms, all sherd motifs from the West New Britain assemblages were recorded using Anson's inventory listing (Anson 1983, table 12). Problems of motif identification were encountered in using the Anson system where, no exact equivalent was found. Specht $(1988: 13)$ also found difficulties in "reconstructing the decisionmaking rules employed by Anson." Anson's motif categories were applied if the identified motif showed close similarity. Where new motifs were found, they were counted separately so that total site motif numbers could be calculated and comparisons made with other sites (Table 4). The FNT (Kreslo) and FSZ (Garua Island) assemblages were included in this analysis. Only the presence or absence of a particular motif was recorded (see Table 5). Although both Anson (1986) and Specht (1988) identified extra motifs from the Talasea assemblages, these motifs were not explicitly described and thus were not added to this analysis.

Three different methods are used to identify and understand the degree of motif sharing between assemblages and regions. First, multivariate analysis is used on the presence/absence of motifs in all sites. Second, a manual indication of motif sharing adapted from Anson is applied. Last, in order to explain the distributions obtained from the first two methods, the distribution of motifs across the already defined regional boundaries are identified.

\section{Multivariate Analysis}

To assess similarity between sites on the basis of motif sharing, a series of multivariate analyses using hierarchical clustering analysis and Principal Components Analysis (PCA) was performed using MVARCH (see Wright 1991). Ward's method was used for the hierarchical clustering analysis. This technique is also known as 
Table 5. Comparison of Motifs Found in the Arawe Assemblages with Sites Used by Anson in His Ph.D. Dissertation

\begin{tabular}{llllllllllllllll}
\hline мотIF & E & T & A & W1 & W2 & W3 & RF2 & RF6 & SZ8 & SZ45 & NC1 & NC2 & NH & F1 & F2 \\
\hline
\end{tabular}

i) FOH Squares $\mathrm{D}, \mathrm{E}$, and $\mathrm{F}$

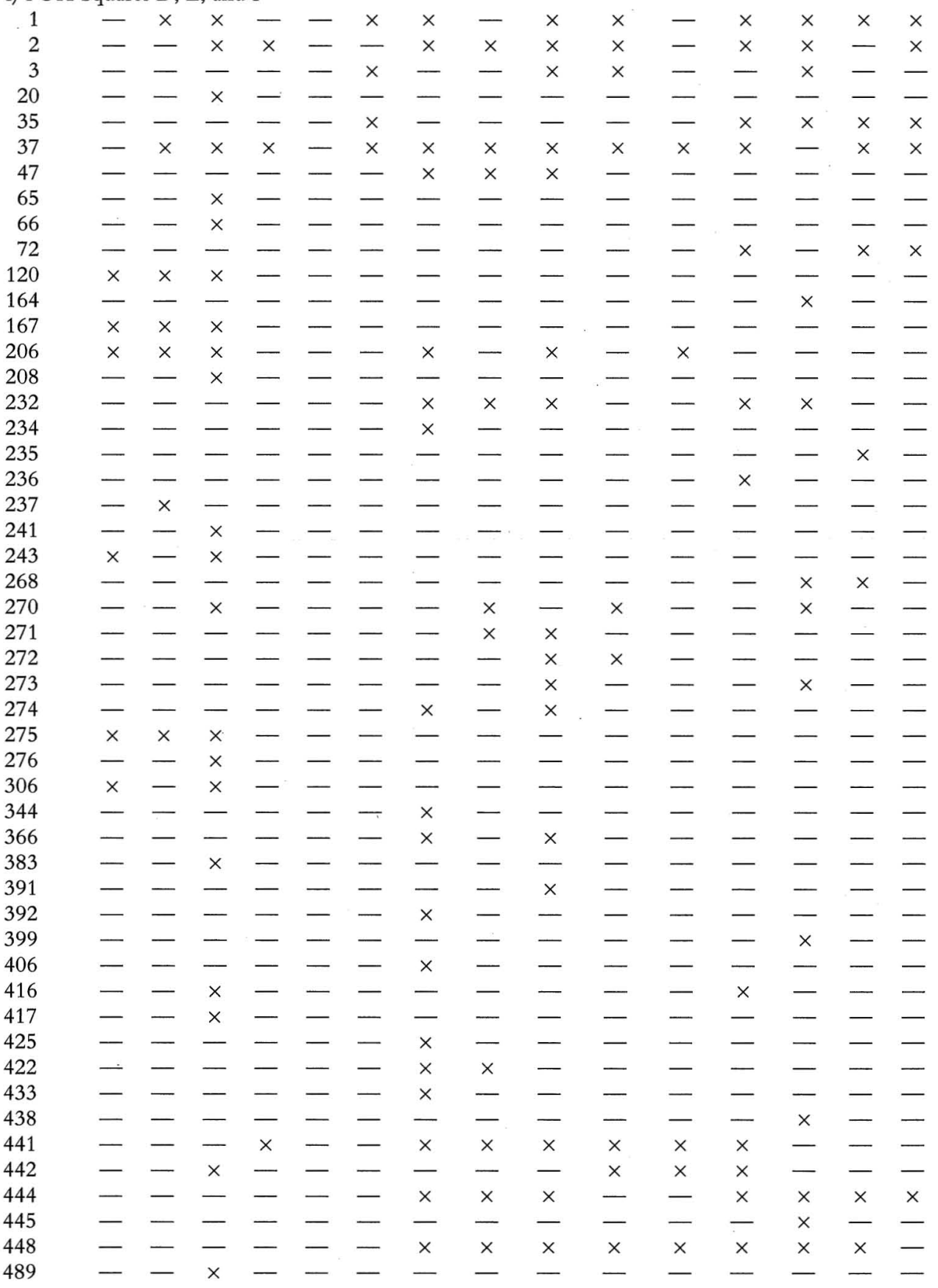

(Continues) 
Table 5. (Continued)

\begin{tabular}{|c|c|c|c|c|c|c|c|c|c|c|c|c|c|c|c|}
\hline MOTIF & $\mathrm{E}$ & $\mathrm{T}$ & A & W1 & W2 & W3 & RF2 & RF6 & SZ8 & SZ45 & NC1 & NC2 & $\mathrm{NH}$ & F1 & $\mathrm{F} 2$ \\
\hline 494 & - & - & - & - & - & - & - & - & - & - & $x$ & $x$ & - & - & - \\
\hline 495 & - & - & - & - & - & - & $\times$ & $\times$ & $x$ & $x$ & - & $x$ & - & - & - \\
\hline 496 & - & - & - & - & - & - & - & - & - & - & $x$ & $x$ & $x$ & $\times$ & - \\
\hline 497 & - & - & - & $x$ & - & $x$ & - & - & $x$ & - & $x$ & $x$ & - & - & - \\
\hline $\begin{array}{l}\text { Shared } \\
\text { motifs }\end{array}$ & 6 & 7 & 21 & 4 & 0 & 5 & 19 & 11 & 18 & 10 & 8 & 16 & 15 & 9 & 6 \\
\hline i) FNY & & & & & & & & & & & & & & & \\
\hline 1 & - & $x$ & $x$ & - & - & $x$ & $x$ & - & $x$ & $x$ & - & $x$ & $x$ & $x$ & $x$ \\
\hline 7 & - & - & - & - & - & - & - & - & - & - & - & - & $x$ & - & - \\
\hline 10 & - & - & $x$ & - & - & - & - & - & - & - & - & - & - & - & - \\
\hline 17 & - & - & - & - & - & - & - & - & - & - & - & $x$ & - & - & - \\
\hline 20 & - & - & $\times$ & - & - & - & - & - & - & - & - & - & - & - & - \\
\hline 30 & - & $x$ & $x$ & - & - & - & - & - & - & - & - & - & - & - & - \\
\hline 31 & - & - & - & - & - & - & - & - & - & $\times$ & - & - & - & - & - \\
\hline 35 & - & - & - & - & - & $x$ & - & - & - & - & - & $x$ & $x$ & $\times$ & $x$ \\
\hline 38 & - & - & - & - & - & - & $\times$ & $x$ & $x$ & - & - & - & - & - & - \\
\hline 45 & - & - & - & - & - & $x$ & $x$ & $x$ & $x$ & - & - & - & - & - & - \\
\hline 53 & - & - & $x$ & $x$ & - & - & $x$ & $x$ & $x$ & $x$ & $x$ & $\times$ & $\times$ & $\times$ & $x$ \\
\hline 54 & - & - & - & $x$ & - & - & $x$ & $x$ & $x$ & $x$ & - & - & $x$ & - & - \\
\hline 70 & - & - & - & - & - & - & - & - & - & - & - & $x$ & - & $\times$ & - \\
\hline 71 & - & - & - & - & - & - & - & - & - & - & - & - & - & $x$ & - \\
\hline 86 & - & - & $x$ & - & - & - & - & - & - & - & - & - & - & - & - \\
\hline 97 & - & - & - & - & - & - & - & - & - & - & - & - & - & $x$ & - \\
\hline 120 & $x$ & $x$ & $x$ & - & - & - & - & - & - & - & - & - & - & - & - \\
\hline 167 & $x$ & $x$ & $x$ & - & - & - & - & - & - & - & - & - & - & - & - \\
\hline 168 & - & - & $x$ & - & - & - & - & - & - & - & - & - & - & - & - \\
\hline 201 & - & - & - & - & - & - & - & - & - & - & - & $x$ & - & - & - \\
\hline 206 & $x$ & $x$ & $x$ & - & - & - & $x$ & - & $x$ & - & $\times$ & - & - & - & - \\
\hline 207 & - & - & $x$ & - & $\times$ & $\times$ & $x$ & $x$ & $x$ & - & $x$ & $x$ & $x$ & $x$ & - \\
\hline 208 & - & - & $x$ & - & - & - & - & - & - & - & - & - & - & - & - \\
\hline 2 & - & - & - & - & - & - & - & - & - & - & - & - & $x$ & - & - \\
\hline 30 & - & - & - & - & - & $x$ & - & - & $x$ & - & - & $x$ & - & $\times$ & $x$ \\
\hline 31 & - & - & - & - & - & - & $x$ & $x$ & $x$ & $x$ & $x$ & $x$ & $\times$ & $x$ & $x$ \\
\hline 35 & - & - & - & - & - & - & - & - & - & - & - & - & - & $x$ & - \\
\hline 36 & - & - & - & - & - & - & - & - & - & - & - & $x$ & - & - & - \\
\hline 237 & - & $x$ & - & - & - & - & - & - & - & - & - & - & - & - & - \\
\hline 38 & - & - & - & - & - & - & - & - & $x$ & - & - & - & - & - & - \\
\hline 40 & - & - & - & - & - & - & - & - & - & - & - & - & $x$ & - & - \\
\hline 241 & - & - & $x$ & - & - & - & - & - & - & - & - & - & - & - & - \\
\hline 242 & - & - & $x$ & - & - & - & - & - & - & - & - & - & - & - & - \\
\hline 251 & - & - & - & - & - & - & $x$ & - & - & - & - & - & - & - & - \\
\hline 72 & - & - & - & - & - & - & - & - & $x$ & $x$ & - & - & - & - & - \\
\hline 275 & $x$ & $x$ & $x$ & - & - & - & - & - & - & - & - & - & - & - & - \\
\hline 306 & $x$ & - & $x$ & - & - & - & - & - & - & - & - & - & - & - & - \\
\hline 345 & - & - & - & - & - & $x$ & - & - & - & - & - & - & - & - & - \\
\hline 364 & - & - & - & - & - & - & - & - & $x$ & - & $x$ & $x$ & - & - & - \\
\hline 377 & - & - & - & $x$ & $x$ & $x$ & - & - & - & - & $x$ & $\times$ & - & - & - \\
\hline 17 & - & - & $x$ & - & - & - & - & - & - & - & - & - & - & - & - \\
\hline 421 & - & - & $\times$ & $\times$ & $\times$ & - & $x$ & $x$ & $x$ & $x$ & $x$ & $\times$ & $x$ & $\times$ & $x$ \\
\hline 426 & - & - & - & - & - & - & $x$ & $\times$ & - & - & - & - & - & - & - \\
\hline 435 & - & - & - & - & - & - & $x$ & - & $x$ & - & - & $x$ & - & - & - \\
\hline
\end{tabular}


TABLe 5. (Continued)

\begin{tabular}{|c|c|c|c|c|c|c|c|c|c|c|c|c|c|c|c|}
\hline MOTIF & $\mathrm{E}$ & $\mathrm{T}$ & A & W1 & W2 & W3 & RF2 & RF6 & SZ8 & SZ45 & NC1 & NC2 & $\mathrm{NH}$ & F1 & $\mathrm{F} 2$ \\
\hline 439 & $x$ & - & $x$ & - & - & - & - & - & - & - & 一 & - & - & - & - \\
\hline 442 & - & - & $x$ & - & - & - & - & - & - & $x$ & $x$ & $x$ & - & - & - \\
\hline 43 & - & - & $x$ & - & - & - & - & - & - & - & - & $x$ & - & - & - \\
\hline 44 & - & - & - & - & - & - & $x$ & $x$ & $x$ & - & - & $x$ & $x$ & $x$ & $x$ \\
\hline 45 & - & - & - & - & - & - & - & - & - & - & - & - & $x$ & - & - \\
\hline 90 & $x$ & - & $x$ & - & - & - & - & - & - & - & - & - & - & - & - \\
\hline 496 & - & - & - & - & - & - & - & - & - & - & $x$ & $x$ & $x$ & $x$ & - \\
\hline $\begin{array}{l}\text { hared } \\
\text { motifs }\end{array}$ & 7 & 7 & 22 & 4 & 3 & 7 & 13 & 9 & 15 & 8 & 9 & 18 & 13 & 13 & 7 \\
\hline \multicolumn{9}{|c|}{ iii) FOH Square G } & & & & & & & \\
\hline 6 & - & - & - & - & - & - & $x$ & $x$ & $x$ & - & - & - & - & - & 一 \\
\hline 35 & - & - & - & - & - & $x$ & - & - & - & - & - & $x$ & $x$ & $x$ & $\times$ \\
\hline 06 & $x$ & $x$ & $x$ & - & - & - & $x$ & - & $x$ & - & $x$ & - & - & - & - \\
\hline 37 & - & $x$ & - & - & - & - & - & - & - & - & - & - & - & - & - \\
\hline 39 & 一 & - & - & - & - & - & - & - & $x$ & - & - & - & - & - & - \\
\hline 68 & - & - & - & - & - & - & - & 一 & - & - & - & - & $x$ & $x$ & - \\
\hline 21 & - & - & $x$ & $x$ & $x$ & - & $x$ & $x$ & $x$ & $x$ & $x$ & $x$ & $x$ & $x$ & $x$ \\
\hline 36 & - & - & - & - & - & - & $x$ & - & - & - & - & - & $x$ & - & - \\
\hline 495 & - & - & - & - & - & - & $x$ & $x$ & $x$ & $x$ & - & $x$ & - & - & - \\
\hline 496 & - & - & - & - & - & - & - & - & - & - & $x$ & $x$ & $x$ & $\times$ & - \\
\hline
\end{tabular}

Shared

$\begin{array}{llllllllllllllll}\text { motifs } & 1 & 2 & 2 & 1 & 1 & 1 & 5 & 3 & 5 & 2 & 3 & 4 & 5 & 4 & 2\end{array}$

iv) FOJ

$\begin{array}{rccccccccccccccc}1 & - & \times & \times & - & - & \times & \times & - & \times & \times & - & \times & \times & \times & \times \\ 3 & - & - & - & - & - & \times & - & - & \times & \times & - & - & \times & - & - \\ 37 & - & \times & \times & \times & - & \times & \times & \times & \times & \times & \times & \times & - & \times & \times \\ 53 & - & - & \times & \times & - & - & \times & \times & \times & \times & \times & \times & \times & \times & \times \\ 206 & \times & \times & \times & - & - & - & \times & - & \times & - & \times & - & - & - & - \\ 207 & - & - & \times & - & \times & \times & \times & \times & \times & - & \times & \times & \times & \times & - \\ 235 & - & - & - & - & - & - & - & - & - & - & - & - & - & \times & - \\ 236 & - & - & - & - & - & - & - & - & - & - & - & \times & - & - & - \\ 237 & - & \times & - & - & - & - & - & - & - & - & - & - & - & - & - \\ 275 & \times & \times & \times & - & - & - & - & - & - & - & - & - & - & - & - \\ 276 & - & - & \times & - & - & - & - & - & - & - & - & - & - & - & - \\ 324 & - & - & - & - & - & - & \times & - & - & - & - & - & - & - & - \\ 327 & - & \times & \times & - & - & - & - & - & - & - & - & - & - & - & - \\ 366 & - & - & - & - & - & - & \times & - & \times & - & - & - & - & - & - \\ 417 & - & - & \times & - & - & - & - & - & - & - & - & - & - & - & - \\ 435 & - & - & - & - & - & - & \times & - & \times & - & - & \times & - & - & - \\ 441 & - & - & - & \times & - & - & \times & \times & \times & \times & \times & \times & - & - & - \\ 448 & - & - & - & - & - & - & \times & \times & \times & \times & \times & \times & \times & \times & - \\ 495 & - & - & - & - & - & - & \times & \times & \times & \times & - & \times & - & - & - \\ 496 & - & - & - & - & - & - & - & - & - & - & \times & \times & \times & \times & -\end{array}$

Shared

$\begin{array}{llllllllllllllll}\text { motifs } & 2 & 6 & 9 & 3 & 1 & 4 & 11 & 6 & 11 & 7 & 7 & 10 & 6 & 7 & 3\end{array}$

v) FSZ

$\begin{array}{rllllllllllllllll}1 & - & \times & \times & - & - & \times & \times & - & \times & \times & - & \times & \times & \times & \times \\ 16 & - & - & - & - & - & \times & - & - & - & - & \times & - & - & - & - \\ 35 & - & - & - & - & - & \times & - & - & - & - & - & \times & \times & \times & \times \\ 73 & - & - & - & \times & - & \times & \times & \times & \times & \times & - & \times & - & - & -\end{array}$

(Continues) 
TABLe 5. (Continued)

\begin{tabular}{|c|c|c|c|c|c|c|c|c|c|c|c|c|c|c|c|}
\hline MOTIF & $\mathrm{E}$ & $\mathrm{T}$ & A & W1 & W2 & W3 & RF2 & RF6 & SZ8 & SZ45 & $\mathrm{NC} 1$ & $\mathrm{NC} 2$ & $\mathrm{NH}$ & F1 & F2 \\
\hline 134 & - & - & - & - & - & - & $x$ & - & $x$ & $x$ & - & - & - & - & - \\
\hline 235 & - & - & - & - & - & - & - & - & - & - & - & - & - & $x$ & - \\
\hline 37 & - & $x$ & - & - & - & - & - & - & - & - & - & - & - & - & - \\
\hline 238 & - & - & - & - & - & - & - & - & $x$ & - & - & - & - & - & - \\
\hline 251 & - & - & - & - & - & - & $x$ & - & - & - & - & - & - & - & - \\
\hline 325 & - & - & - & - & - & $x$ & - & - & - & - & - & - & - & $x$ & - \\
\hline 66 & - & - & - & - & - & - & $x$ & - & $x$ & - & - & - & - & - & - \\
\hline 91 & - & - & - & - & - & - & - & - & $x$ & - & - & - & - & - & - \\
\hline 408 & - & - & - & $x$ & - & $\times$ & $x$ & $\times$ & $x$ & - & - & - & $x$ & - & - \\
\hline 495 & - & - & - & - & - & - & $x$ & $\times$ & $x$ & $x$ & - & $x$ & - & - & - \\
\hline 496 & - & - & - & - & - & - & - & - & - & - & $x$ & $x$ & $x$ & $\times$ & - \\
\hline $\begin{array}{l}\text { Shared } \\
\text { motifs }\end{array}$ & - & 2 & 1 & 2 & - & 6 & 7 & 3 & 8 & 4 & 2 & 5 & 4 & 5 & 2 \\
\hline vi) FNT & & & & & & & & & & & & & & & \\
\hline 3 & - & - & - & - & - & ૪ & - & - & - & - & - & $x$ & $x$ & $\times$ & $x$ \\
\hline 133 & - & - & - & $x$ & - & ? & - & - & - & $x$ & - & - & - & - & - \\
\hline 207 & - & - & $x$ & - & $x$ & $x$ & $x$ & $x$ & $x$ & - & $x$ & $x$ & $x$ & $x$ & - \\
\hline 237 & - & $x$ & - & - & - & - & - & - & - & - & - & - & - & - & - \\
\hline 385 & - & - & - & - & - & - & $x$ & - & - & - & - & - & - & - & - \\
\hline 435 & - & - & - & - & - & - & $x$ & - & $x$ & - & - & $x$ & - & - & - \\
\hline 447 & - & - & - & - & - & - & - & - & - & - & - & $x$ & - & - & - \\
\hline 496 & - & - & - & - & - & - & - & - & - & - & $x$ & $x$ & $x$ & $x$ & - \\
\hline $\begin{array}{l}\text { Shared } \\
\text { motifs }\end{array}$ & - & 1 & 1 & 1 & 1 & 3 & 3 & 1 & 2 & 1 & 2 & 5 & 3 & 3 & 1 \\
\hline
\end{tabular}

$\mathrm{E}=\mathrm{ECA}$ Egloff's excavation, Eloaua; $\mathrm{T}=\mathrm{FCR} / \mathrm{FCS}$ Talasea; $\mathrm{A}=\mathrm{EAQ}$ Malekolon Plantation, Ambitle, both the Carson collection housed at the Australian Museum and Ambrose's excavations; $\mathrm{W} 1=\mathrm{SAD}$ Watom site 6 ; $\mathrm{W} 2=\mathrm{SAC}$ Watom site 8 ; W3 = Watom Meyer collection; RF2 = Reef Islands SE-RF2 site; RF6 = Reef Islands SE-RF6 site; SZ8 = Santa Cruz SE-SZ8 site; SZ45 = Santa Cruz SE-SZ45 site; NC1 = Ile des Pins, New Caledonia; NC2 = Site 13 Lapita site, New Caledonia; NH = Malo, Vanuatu; F1 = Yanuca, Fiji; F2 = Natunuku, Fiji.

Note. Both the Carson collection and Ambrose excavated sherds from Ambitle have been lumped in one general Ambitle heading, as per Anson 1986. I have kept Watom 2 and 3 separate unlike Anson who regroups them (Anson 1987:127).

the error sum of squares method (Baxter 1994:142) and works on within group sum of square distances: "At each stage the number of groups is reduced by one; by combining the two groups which give the smallest possible increase in the total within group sum of squares ... when (one) starts with $\mathrm{n}$ groups of one individual, the total within group sum of squares is zero" (Chatfield and Collins $1980: 224$ ).

Ward's method will "amalgamate clusters on the basis of similarity between groups rather than just between a pair of individuals" (Baxter 1994:146). The drawback of using Ward's method is that it produces spherical clusters of equal size even if the data are random (Baxter 1994:158). This problem can be overcome by comparisons with the PCA plot.

The only limitation in multivariate analysis could be the bias inherent in comparing one assemblage, such as RF-2, which has 178 different motifs, with FCR/ FCS, which has only 16 different motif forms, although Anson (1986:161) argues that "the results do not appear to be affected by the size of samples." Sample size 


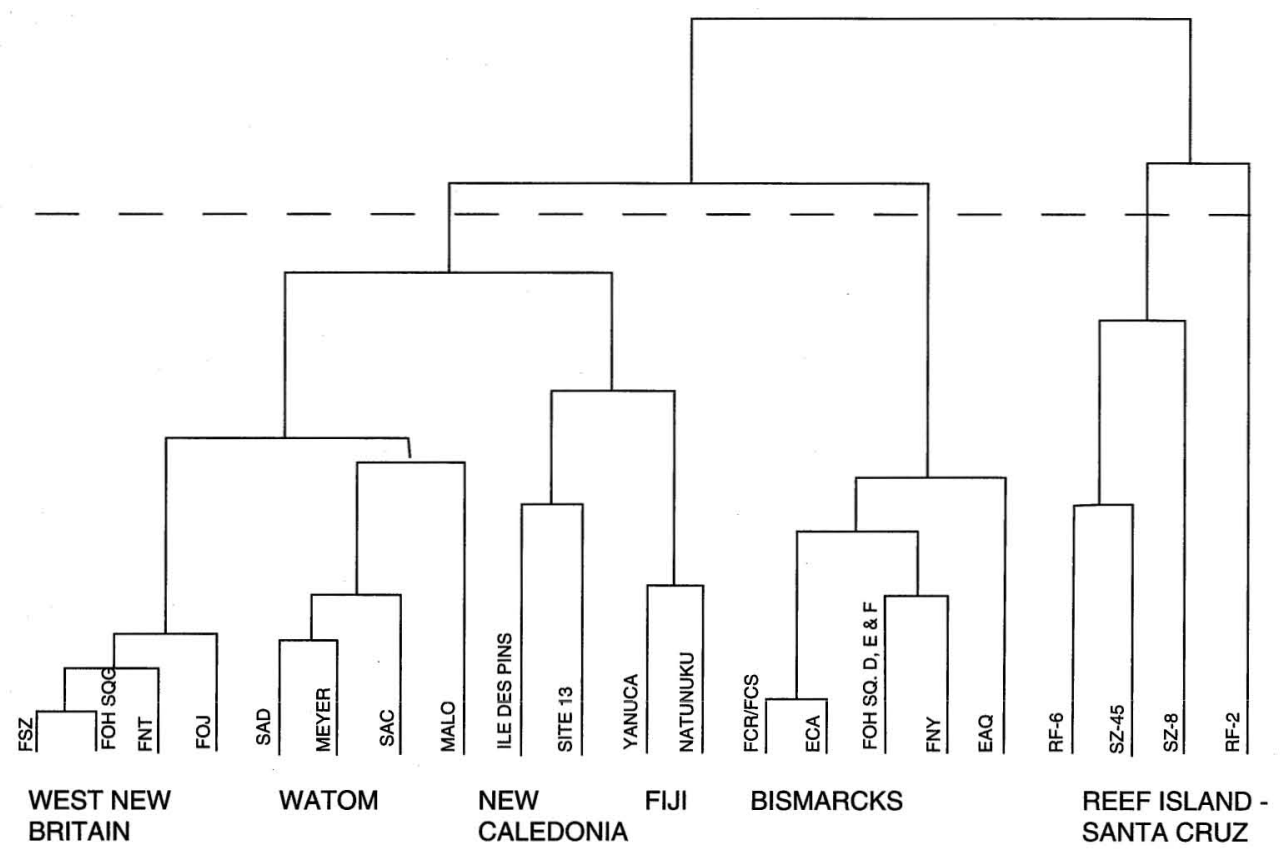

3ii

$3 \mathbf{i}$

2

1

Fig. 5. Grouping of sites based on motif similarity using Ward's hierarchical clustering analysis.

does have some effect on the placement of RF-2 only, but does not affect its placement with other Reef/Santa Cruz sites and their relationship with other sites (see below).

On both the dendrogram and PCA three major clusters are defined (Figs. 5 and 6).

1. The first separates out the four Reef/Santa Cruz sites. On the dendrogram this cluster could technically be called two, with RF-2 forming a separate cluster by itself. On the PCA plot the Reef/Santa Cruz sites separate from the rest on the first component ( $\mathrm{x}$-axis), with RF-2 being the furthermost assemblage from the others. Although sample size can not be totally discounted in the separation of RF-2 from the other Reef/Santa Cruz, it is not the only factor. Its relationship with the other Reef/Santa Cruz sites and their separation as a group from the other assemblages is not a factor of sample size.

2. The second cluster comprises FCR/FCS (Talasea), ECA (Eloaua), FOH (Adwe) squares D/E/F, FNY (Paligmete), and EAQ (Ambitle).

3. The third cluster subdivides into two: (i) both Fijian sites (Natunuku and Yanuca) and two New Caledonian (site 13 and Ile des Pins) sites; (ii) the rest of the Bismarck sites plus Vanuatu. Two subclusters are present. The first groups all Watom assemblages and Vanuatu (Malo), while the second groups FSZ (Garua Island), FOH (Adwe) square G, FNT (Kreslo), and FOJ (Apalo). Each of these sites from the Bismarcks is stylistically closer to all the others than it is to other Western assemblages (see Table 6 for their nearest neighbors). 


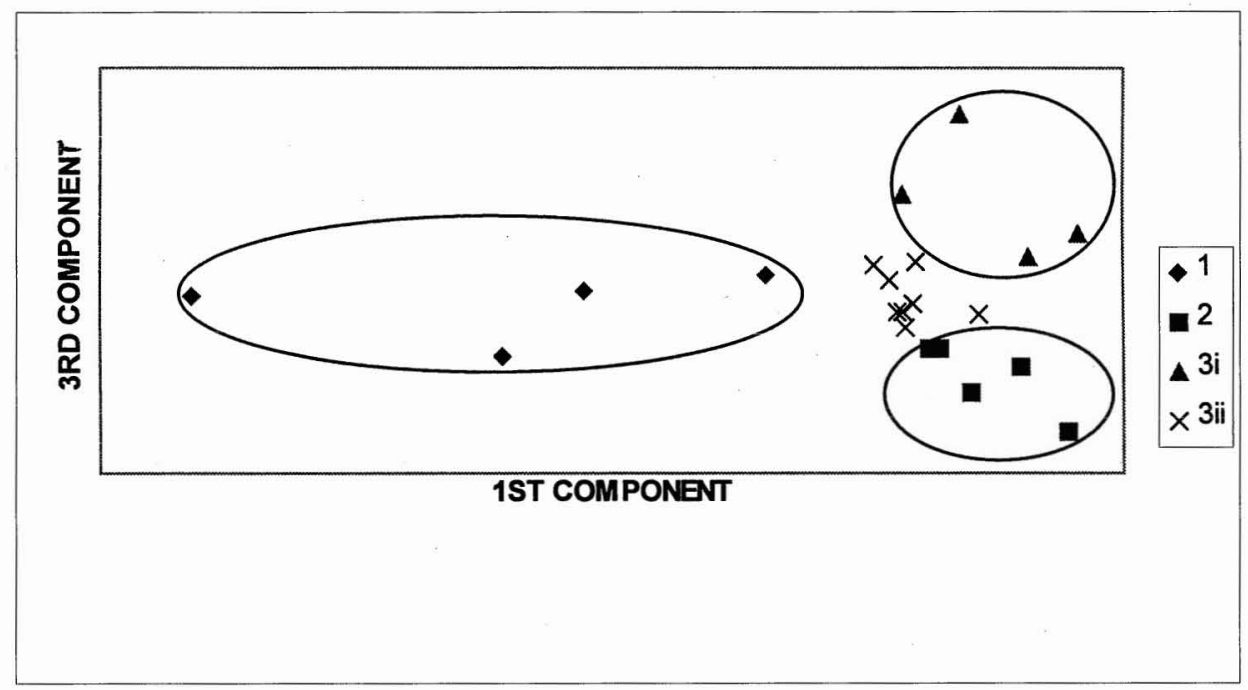

Fig. 6. Grouping of sites based on motif similarity using PCA (1st and 3rd components).

Table 6. Nearest Neighbors Table of West New Britain Sites (with Distances to Their Nearest Three Neighbors)

\begin{tabular}{llll}
\hline SITE & \multicolumn{1}{c}{1} & 2 & 3 \\
\hline FNY & FOH Sq. D/E/F & ECA & FCR/FCS \\
& $(.03)$ & $(.04)$ & $(.04)$ \\
FOH Sq. D/E/F & FNY & ECA & FCR/FCS \\
& $(.03)$ & $(.04)$ & $(.04)$ \\
FOJ & FOH Sq. G & FSZ & FNT \\
FOH Sq. G & $(.01)$ & $(.01)$ & $(.02)$ \\
& FSZ & FNT & FOJ \\
FNT & $(.01)$ & $(.01)$ & $(.01)$ \\
& FOH Sq. G & FSZ & $(.01)$ \\
FSZ & $(.01)$ & FNT & $(.02)$ \\
& FOH Sq. G & $(.01)$ & FOJ \\
\hline
\end{tabular}

The West New Britain assemblages under study divide into two. FOH squares D/E/F and FNY group with Anson's Far Western assemblages, while the rest group with the Western assemblages. Note that on the PCA plots, the Bismarck Western assemblages of FNT, FSZ, FOJ, and FOH square G are intermediate between the Far Western sites and Watom. The assemblages from New Caledonia and Fiji separate even further. Therefore, although the Bismarck Western sites group with other Western sites, they still remain close to the Far Western assemblages from the Bismarcks.

To explore further the sharing of motifs across these assemblages, a similarity measure used by Anson was applied. When comparing two sites, he calculated the number of shared motifs as a percentage of the maximum number of motifs that theoretically could be shared. Anson gives an example by comparing Watom with 
Ambitle: "with 26 motif types present on Watom and the 19 motif types in the Ambitle sample it is theoretically possible for the two samples to share up to 19 motif types. In reality they share only two, i.e., 2/19"-10 percent (Anson 1983, $1987: 127)$. Note that in his 1986 article Anson uses an enlarged motif listing from Eloaua. As this motif listing was not available to me, it is not used in the following calculations.

Kay's motif analysis from Naigani is used in this analysis (NA in Table 7) (Kay 1984). Table 7 shows that whereas sites FOH square G, FOJ, FNT, and FSZ have similarity indexes of over 30 percent with many of the Western and Eastern sites, the Arawe Far Western sites of FOH squares D/E/F, and FNY do not. Such a distinction between the Arawe sites was noted in respect to both the percentage of dentate decoration and the forms of the dentate vessels (Summerhayes 2000a: 155). Yet despite this separateness, both sets of Arawe assemblages and those from FNT and FSZ have a high degree of similarity with all Bismarck sites excluding Watom sites SAD and SAC. Although more similarity is evident between the later Arawe assemblages and those further east (lack of Far Western motifs, less dentate decoration, lower percentage of dentate bowls and stands), these West New Britain assemblages also exhibit strong regional similarities absent from the Watom assemblages.

\section{Distribution of Motifs across Regions}

To understand the structure of the hierarchical clustering analysis, an appreciation of the regional distribution of motifs is needed. Because Anson defined regional groups on the basis of motif similarity, the identification of motifs and their contribution to the definition of regional styles is necessary. To do this, motifs were divided into a number of categories depending on their regional occurrence: Far Western, Western, Far Western and Western, Western/Eastern, Eastern, common to all areas, area specific (i.e., Reef/Santa Cruz or New Caledonia or Watom only), and site specific. If, for example, a motif was only found in Anson's Far Western sites of Eloaua, Ambitle, or Talasea, then that motif is classified as a Far Western motif. If it is found across all regions, then it is designated a common motif. If it is found in the Far Western sites and Vanuatu, it is designated a Far Western/ Western motif. Table 8 presents the results.

The distribution confirms the separation of FOH squares D/E/F and FNY with FOH square $G$, as originally defined by the percentage of dentate on sherds and vessels. On the other hand, FOJ has four motifs (15 percent of all motifs) found otherwise only in the Bismarcks Far Western assemblages. These, however, came from one vessel, a pot stand, found in unit C.

The distinction between the two groups of sites shown above is also directly related to the decrease of bowls that account for the majority of dentate vessels (see Summerhayes 2000 b). When the distribution of vessel form per motif category for the Arawes was combined, it was noted that motifs associated with Eastern sites are not found on bowls or stands in the Arawe assemblages (see Summerhayes $2000 a: 163$, figs. 10.13, 10.14). Also of note is the high proportion of Eastern motifs that are shared with Western assemblages (W/E).

In conclusion, the Arawe assemblages group into two (FOH squares $\mathrm{D} / \mathrm{E} / \mathrm{F}$ plus FNY, and FOJ plus FOH square G) on the basis of 
Table 7. Site Similarity as Defined by Motif Sharing

\begin{tabular}{|c|c|c|c|c|c|c|c|c|c|c|c|c|c|c|c|c|c|c|c|c|c|c|}
\hline & & & $\mathrm{FOH}$ & & & & FCR/ & & & & & & & & & & & & & & & \\
\hline & $\mathrm{D} / \mathrm{E} / \mathrm{F}$ & FNY & G & FOJ & FNT & FSZ & FCS & ECA & EAQ & W1 & W2 & W3 & RF2 & RF6 & SZ8 & SZ45 & $\mathrm{NC1}$ & $\mathrm{NC} 2$ & $\mathrm{NH}$ & $\mathrm{F} 1$ & $\mathrm{~F} 2$ & NA \\
\hline $\mathrm{FOH} \mathrm{D/E} / \mathrm{F}$ & . & 31 & 50 & 56 & 38 & 53 & 44 & 60 & 30 & 15 & 0 & 11 & 20 & 13 & 20 & 17 & 17 & 18 & 17 & 13 & 11 & 10 \\
\hline FNY & 31 & & 42 & 41 & 63 & 47 & 44 & 70 & 35 & 15 & 27 & 16 & 21 & 15 & 24 & 13 & 20 & 29 & 21 & 21 & 2 & 13 \\
\hline $\mathrm{FOH} \mathrm{G}$ & 50 & 42 & & 33 & 38 & 33 & 17 & 10 & 17 & 8 & 9 & 8 & 42 & 25 & 42 & 17 & 25 & 33 & 42 & 33 & 17 & 17 \\
\hline $\mathrm{FOJ}$ & 56 & 41 & 33 & & 50 & 40 & 38 & 20 & 33 & 12 & 9 & 15 & 41 & 22 & 41 & 26 & 26 & 37 & 22 & 26 & 11 & 26 \\
\hline FNT & 38 & 63 & 38 & 50 & & 38 & 13 & 0 & 13 & 13 & 13 & 38 & 38 & 13 & 25 & 13 & 25 & 63 & 38 & 38 & 13 & 40 \\
\hline FSZ & 53 & 47 & 33 & 40 & 38 & & 20 & 0 & 7 & 0 & 20 & 40 & 20 & 20 & 20 & 0 & 20 & 60 & 60 & 40 & 20 & 50 \\
\hline FCR/FCS & 44 & 44 & 17 & 38 & 13 & 13 & & 50 & 75 & 6 & 0 & 13 & 31 & 19 & 31 & 19 & 13 & 19 & 13 & 13 & 13 & 25 \\
\hline ECA & 60 & 70 & 10 & 20 & 0 & 0 & 50 & & 100 & 0 & 0 & 0 & 10 & 0 & 10 & 0 & 10 & 0 & 0 & 0 & 0 & 0 \\
\hline EAQ & 30 & 35 & 17 & 33 & 13 & 7 & 75 & 100 & & 35 & 55 & 22 & 20 & 16 & 23 & 17 & 20 & 25 & 17 & 12 & 15 & 12 \\
\hline W1 & 15 & 15 & 8 & 12 & 13 & 13 & 6 & 0 & 35 & & 55 & 46 & 46 & 38 & 54 & 38 & 42 & 54 & 27 & 19 & 27 & 12 \\
\hline W2 & 0 & 27 & 9 & 9 & 13 & 0 & 0 & 0 & 55 & 55 & & 55 & 73 & 36 & 45 & 27 & 55 & 82 & 45 & 36 & 27 & 27 \\
\hline W3 & 11 & 16 & 8 & 15 & 38 & 40 & 13 & 0 & 22 & 46 & 55 & & 29 & 22 & 38 & 18 & 22 & 38 & 24 & 18 & 13 & 18 \\
\hline RF2 & 20 & 21 & 42 & 41 & 38 & 47 & 31 & 10 & 20 & 46 & 73 & 29 & & 63 & 47 & 48 & 39 & 31 & 27 & 20 & 17 & 20 \\
\hline RF6 & 13 & 15 & 25 & 22 & 13 & 20 & 19 & 0 & 16 & 38 & 36 & 22 & 63 & & 58 & 38 & 24 & 25 & 22 & 14 & 15 & 15 \\
\hline SZ8 & 20 & 24 & 42 & 41 & 25 & 53 & 31 & 10 & 23 & 54 & 45 & 38 & 47 & 58 & & 48 & 35 & 30 & 30 & 17 & 20 & 18 \\
\hline SZ45 & 17 & 13 & 17 & 26 & 13 & 27 & 19 & 0 & 17 & 38 & 27 & 18 & 48 & 38 & 48 & & 30 & 30 & 25 & 13 & 13 & 15 \\
\hline NC1 & 17 & 20 & 25 & 26 & 25 & 13 & 13 & 10 & 20 & 42 & 55 & 22 & 39 & 24 & 35 & 30 & & 70 & 17 & 15 & 9 & 22 \\
\hline NC2 & 18 & 29 & 33 & 37 & 63 & 33 & 19 & 0 & 25 & 54 & 82 & 38 & 31 & 25 & 30 & 30 & 70 & & 22 & 23 & 24 & 19 \\
\hline $\mathrm{NH}$ & 17 & 21 & 42 & 22 & 38 & 27 & 13 & 0 & 17 & 27 & 45 & 24 & 27 & 22 & 30 & 25 & 17 & 22 & & 20 & 20 & 17 \\
\hline $\mathrm{F} 1$ & 13 & 21 & 33 & 26 & 38 & 33 & 13 & 0 & 12 & 19 & 36 & 18 & 20 & 14 & 17 & 13 & 15 & 23 & 20 & & 37 & 17 \\
\hline $\mathrm{F} 2$ & 11 & 13 & 17 & 11 & 13 & 13 & 13 & 0 & 15 & 27 & 27 & 13 & 17 & 15 & 20 & 13 & 9 & 24 & 20 & 37 & & 17 \\
\hline NA & 10 & 13 & 17 & 26 & 40 & 50 & 25 & 0 & 12 & 12 & 27 & 18 & 20 & 15 & 18 & 15 & 22 & 22 & 19 & 17 & 17 & \\
\hline
\end{tabular}

FCR $/ F C S=$ Talasea; ECA = Egloff's excavation, Eloaua; EAQ = Malekolon Plantation, Ambitle, both the Carson collection housed at the Australian Museum and Ambrose's excavations; W1 = SAD Watom site 6; W2 = SAC Watom site 8; W3 = Watom Meyer collection; RF2 = Reef Islands SE-RF2 site; RF6 = Reef Islands SE-RF6 site; SZ8 = Santa Cruz SE-SZ8 site; SZ45 = Santa Cruz SE-SZ45 site; NC1 = Ile des Pins, New Caledonia; NC2 = Site 13 Lapita site, New Caledonia; NH = Malo, Vanuatu; F1 = Yanuca, Fiji; F2 = Natunuku, Fiji; Na = Naigani, Fiji. 
Table 8. Percentage of Motifs Designated to Style Areas

\begin{tabular}{lrrrrrrr}
\hline SITE & FW & FW/W & W & W/E & E & C & UNIQUE \\
\hline FOH Sq. D, E, F & 15 & 5 & 26 & 6 & 1 & 3 & 42 \\
FNY & 26 & 5 & 31 & 10 & 5 & 8 & 16 \\
FOJ & 15 & 7 & 22 & 11 & 4 & 15 & 26 \\
FOH Sq. G & 0 & 17 & 25 & 33 & 0 & 8 & 17 \\
FSZ & 0 & 7 & 60 & 20 & 7 & 7 & 0 \\
FNT & 0 & 12 & 50 & 25 & 0 & 12 & 0 \\
EAQ & 14 & 22 & 0 & 0 & 0 & 14 & 49 \\
FCR/FCS & 44 & 19 & 0 & 0 & 0 & 12 & 25 \\
ECA & 90 & 10 & 0 & 0 & 0 & 0 & 0 \\
SAD & 0 & 8 & 50 & 0 & 0 & 29 & 12 \\
SAC & 0 & 9 & 27 & 0 & 0 & 45 & 18 \\
Watom (Meyer) & 0 & 10 & 49 & 5 & 0 & 15 & 22 \\
SE-RF-2 & 0 & 3 & 16 & 4 & 0 & 5 & 72 \\
SE-RF-6 & 0 & 5 & 23 & 6 & 0 & 9 & 57 \\
SE-SZ-8 & 0 & 5 & 23 & 5 & 0 & 0 & 60 \\
SE-SZ-45 & 0 & 8 & 35 & 2 & 0 & 10 & 45 \\
Malo & 0 & 6 & 16 & 16 & 0 & 8 & 53 \\
Ile des Pins & 0 & 11 & 39 & 6 & 0 & 9 & 35 \\
Site 13 & 0 & 10 & 25 & 12 & 0 & 11 & 43 \\
Yanuca & 0 & 0 & 0 & 22 & 0 & 11 & 66 \\
Natunuka & 0 & 0 & 0 & 18 & 0 & 15 & 67 \\
Naigani & 0 & 3 & 29 & 5 & 4 & 3 & 56 \\
\hline
\end{tabular}

1. percentages of dentate decoration,

2. different vessel proportions,

3. geographically shared motifs.

Both FNT and FSZ group with FOJ plus FOH square G on the basis of motif similarity. Note that a detailed petrographic and chemical characterization analysis demonstrated that any stylistic similarities among these West New Britain assemblages are not due to the movement of pots through exchange (see Summerhayes $2000 a)$.

\section{Motif Sharing between the West New Britain and Eastern Lapita Assemblages}

Some significant Eastern Lapita assemblages were not incorporated into the Anson system. To assess the relationship between these assemblages and those from West New Britain, an attempt is made to incorporate them into the Anson system. See Appendix 1 for a listing of Anson motifs found in the following assemblages: Tonga, Naigani, Niuatoputapu, Tikopia, Futuna, and Mulifanua.

With the addition of the West New Britain assemblages to the corpus of Lapita pottery, motifs once seen as contributing to the uniqueness of the easterly sites are now seen to be present in the later assemblages of West New Britain. Motifs found in Tikopia, which Kirch (1988a:187) saw as deriving from a Niuatoputapu (NT-90)/Uvea/Mulifanua complex, are also found in the West New Britain assemblages. With better defined sequences from West New Britain it is no longer necessary to look for an eastern derivation for the Tikopia assemblages as Kirch and Yen 
Table 9. Chronological and Spatial Spread of Early, Middle, and Late Lapita

\begin{tabular}{|c|c|c|c|c|}
\hline $\begin{array}{l}\text { NEW } \\
\text { TERM }\end{array}$ & $\begin{array}{c}\text { OLD } \\
\text { PROVINCE }\end{array}$ & BISMARCK ARCHIPELAGO & $\begin{array}{c}\text { SOLOMONS, VANUATU, } \\
\text { NEW CALEDONIA }\end{array}$ & FIJI, TONGA, SAMOA \\
\hline & & & & $\begin{array}{l}\text { Samoa } 2750 \text { cal B.P. } \\
\text { (Dickinson and } \\
\text { Green 1998) }\end{array}$ \\
\hline \multirow[t]{3}{*}{ Late } & Eastern & $\begin{array}{l}\text { FSZ 2798-2137 cal в.P. } \\
\text { (Torrence pers. comm.) } \\
\text { FOJ 2760-2350 cal в.P. } \\
\text { (Specht and Gosden 1997) }\end{array}$ & $\begin{array}{l}\text { Tikopia } 2680 \text { в.P. } \\
\text { (Kirch 1997) }\end{array}$ & $\begin{array}{l}\text { Tonga } 2850 \text { cal B.P. } \\
\text { (Burley } 1998 ; \\
\text { Burley et al. 1999) }\end{array}$ \\
\hline & & & & $\begin{array}{l}\text { Fiji } 2800-2700 \mathrm{cal} \\
\text { B.P. (Anderson } \\
\text { and Clark 1999) }\end{array}$ \\
\hline & & & $\begin{array}{l}\text { Reef/Santa Cruz } \\
\text { SE-SZ-8 } 3140 \text { B.P. } \\
\text { (Green 1991b) }\end{array}$ & \\
\hline Middle & Western & $\begin{array}{l}\text { FOJ } 2950-2750 \text { cal в.P., } \\
\text { FOH Sq. G 2950-2500 } \\
\text { cal B.P. (Specht and } \\
\text { Gosden 1997) }\end{array}$ & $\begin{array}{r}\text { New Caledonia } 2950 \\
\text { cal B.P. (Sand 1997) }\end{array}$ & \\
\hline \multirow[t]{4}{*}{ Early } & Far Western & Bismarck Archipelago 3500 & & \\
\hline & & B.P. (Spriggs 1996, Kirch & & \\
\hline & & 1997) & & \\
\hline & & $\begin{array}{l}\text { West New Britain } 3300 \mathrm{cal} \\
\text { B.P. (Specht and Gosden } \\
\text { 1997) }\end{array}$ & & \\
\hline
\end{tabular}

(1982:337-338) have done. Its similarity with the Eastern sites is now offset by similarity, too, with Western sites.

\section{DISCUSSION}

The addition of the new West New Britain assemblages confirms the unique corpus of motifs found previously in the Talasea-FCR/FCS, Eloaua-ECA, and Ambitle-EAQ assemblages from the Bismarcks. Yet their addition also confirms the greater corpus of motifs shared between all areas. Indeed the pottery from both the $\mathrm{FOH}$ squares $\mathrm{D} / \mathrm{E} / \mathrm{F}$, and FNY (which group with the Far Western sites), and FOJ, FNT, and FSZ assemblages, have motifs that have been identified in the so-called Western and Eastern style provinces. Yet these motifs are absent in the EAQ, ECA, and FCR/FCS assemblages.

This pattern has a direct bearing on a question posed by Kirch et al. (1987: 125) on whether with the addition of more sites, the Bismarck Archipelago assemblages "will remain distinct and internally homogeneous, or diverge from one another as samples become larger." Kirch posed the question in order to throw doubt on Anson's definition of a Far Western style based on small sherd numbers from three sites. The addition of more sites and motifs has, as Kirch predicted, increased the number of motifs shared between regions, yet a more complex picture emerges. First, sites such as FOH square G, FOJ, FSZ, and FNT group closely with Western sites. Secondly, FOH squares D/E/F and FNY also 
confirm the distinctiveness of the Far Western group of sites from others in the region that cluster with those further east. Specht $(1988: 8)$ has also shown that the addition of more motifs from Watom and Boduna does not reduce the differences between regions.

This analysis has three major implications:

1. The Lapita stylistic provinces are temporal more than spatial phenomenon (see Table 9). As Anson (1983:163) had hoped, the excavation of more sites from West New Britain has shed new light on the definition of stylistic boundaries. The results from the analyses presented here have tended to diminish differences between stylistic provinces. For instance, the Eastern Lapita style is seen to have similarities with late Bismarck Archipelago assemblages. Thus I suggest that Far Western be replaced with Early Lapita, Western with Middle Lapita, and Eastern with Late Lapita (see Table 9).

2. Similarities across space do not result just from the initial dispersal but from continued widespread interaction. The sharing of similar dentate motifs, once seen as restricted to the east only, and other decorative elements such as shell impression, which is not found in the early Far Western assemblages, points to continued two-way interaction between these areas. These motifs once restricted to the east and now identified in the west were not part of the early corpus of motifs which accompanied the initial colonization of Remote Oceania. They are not found in the earlier assemblages of the Santa Cruz and Reef Islands, Vanuatu, or New Caledonia but only in a few later assemblages.

Regional differences did exist. Two dimensions, temporal and regional, were at play (Green 1978). The decorative changes occurring in both the west and east Lapita regions, in particular the simplification of the motif repertoire, suggests similar socio-economic changes occurring in the societies that produced and consumed the ceramics. The idea that the water gap between Vanuatu and Fiji inhibited two-way voyaging has been thrown into doubt by Irwin (1992) - twoway voyages were always feasible. However one way (west to east) was more difficult than the other, so the ceramic evidence does not necessarily mean that the frequency of contact was high. The nature of the data allows the identification of continued interaction, not its frequency. The use of motifs in identifying interaction is important as they are seen as social/ideological signifiers that are socially active, meaningful, and maintain social boundaries (see Summerhayes $2000 \mathrm{~b}$ for further discussion). Interaction does not equate with nor need to be confirmed by the physical movement of obsidian or other goods, which have different economic roles to play. Similar changes in the Lapita decorative system occur in the west and east. These similarities were not the product of ceramic exchange (Summerhayes 2000a). They were the products of information exchange, which requires the movement of ideas. Communication was ongoing, indicating a more socially interactive set of networks.

The simplification of Lapita dentate design decoration (or, as others have put it, the declining intensity of labor or energy put into producing dentate pottery) and the appearance of incised, applied and relief, and shell-impressed ware, occur across both space and time-from west to east (see Green's distance decay model: 1978, 1979) and from Far Western and Western to late Western in the Bismarcks. To use Green's words, the change "from the rather ornate curvilinear and fairly elaborate rectilinear design patterns of the western Lapita to the more simplified and generally rectilinear forms of the eastern Lapita" (Green 1979:42) could be 
just as appropriate to describe the change within assemblages in West New Britain or those from Mussau. Within the Arawe assemblages these changes are also accompanied by changes in vessel forms with a decline in dentate vessel forms (bowls and stands) over time and while nondentate vessels (plain globular pots, plain bowls, and incised carinated jars) remain relatively unchanged (see Summerhayes 2000b).

3. Anson's notion of a Far Western substyle in the Bismarck Archipelago before settlement of the rest of the Pacific is confirmed. This throws doubt on the model that the spread of Austronesian populations out from the west into Remote Oceania was archaeologically instantaneous, and that any unique motifs found in the Bismarck Archipelago were due to "local stylistic divergence" (Kirch et al. 1987:126).

This is borne out by recent research into the dating of Lapita assemblages from Fiji and Tonga that does not support Lapita colonization as archaeologically instantaneous. Table 9 illustrates the appearance of Lapita from the Bismarck Archipelago (3500-3300 B.P.), the Solomons (3140 B.P.), New Caledonia (2950 B.P.), Fiji (2800 B.P.), and Tonga (2850 в.P.) (see Anderson and Clarke 1999; Burley et al. 1999; Dickinson and Green 1998; Green 1991b; Sand 1996, 1997; Specht and Gosden 1997). The dates for initial occupation from Tonga and Fiji are commensurate with radiocarbon age estimates for the later Western assemblages of FOH square $\mathrm{G}$ and FOJ Apalo. Fine tuning the dating of these changes within West New Britain assemblages is problematical at present. What is needed is not only a better definition of the pottery changes from Middle to Late Lapita, but also a better resolution of when the changes happened in West New Britain. This problem, however, does not detract from the point made here that motifs once thought to be unique to the Eastern Lapita assemblages, and used to argue for the isolation of sites in Fiji, Tonga, and Samoa from those further west, are now shown to be found in the Bismarck Archipelago. This suggests that this style is no longer an indicator of solely spatial isolation, as one would expect if the distribution in Tables 1 or 2 proved to be correct. Indeed, its presence throughout the western Pacific suggests that both space and time played roles, and time in the ceramic decorative system is the stronger component (Table 9).

\section{CONCLUSION}

It is argued on stylistic grounds that a development from a Far Western to Western style is evident from assemblages in West New Britain. This adds credence to an earlier pause in the Bismarck Archipelago. Such a conclusion is borne out by recent research into the dating of Pacific assemblages, which confirms that settlement from the Bismarcks into the Pacific was sequential (Table 9). These earliest ceramic assemblages show that the makers of this pottery were people with no specialist ceramic production centers, as the pottery making was predominantly local, but who had an elaborate and cohesive social interaction network that can be measured by ceramic homogeneity.

The later assemblages found further afield in the western Pacific are testimony to the expansion of settlements and colonization of areas not previously occupied. These settlements, like contemporaries to the west, also exhibit ceramic homogeneity indicating production by people with elaborate and cohesive social interaction networks. Yet it is argued here that there is no geographic divide, and 
therefore terms such as Western and Eastern are misleading and should be abandoned and replaced. The fundamental nature of interaction did not change at the end of this colonization process, with the ceramics in the Eastern Lapita region showing little fundamental differences to those later assemblages from West New Britain.

\section{ACKNOWLEDGMENTS}

I'd like to acknowledge three colleagues whose seminal work on Pacific prehistory has influenced my own work: Jack Golson, Roger Green, and Pat Kirch. Roger Green has also provided valuable comments on this paper. I am indebted to Jim Specht, Chris Gosden, Robin Torrence, Christina Pavlides, and Richard Fullagar, with whom I have worked closely in Papua New Guinea. J. Peter White and Jim Allen offered advice and encouragement over the course of this research. Jim Specht, Robin Torrence, Geoff Clark, Matthew Spriggs, Atholl Anderson, and Michael Graves commented on this paper and I thank them. Thanks also to Matthew Phelan who provided advice on radiocarbon matters.

Fieldwork in Papua New Guinea was made possible by ARC grants to Chris Gosden and Jim Specht, and to Robin Torrence. The assistance of the following institutions in Papua New Guinea is also acknowledged: the National Research Institute, the National Museum and Art Gallery, the Department of Anthropology and Sociology, University of Papua New Guinea, and the West New Britain Provincial Government. In particular I'd like to thank Pamela Swadling, Baiva Ivuyo, Herman Mandui, Robert Mondol, Nick Araho, Wilfred Oltomo, Jacob Simmet, John Muke, Jo Mangi, Charles Rukuva, and John Namuno.

In the Arawe Islands a special thank you to the communities of Pililo Island, Kumbun Island, Amalut and Maklo Island. Thanks also to Max and Cecilie Benjamin, Walindi Plantation, for their cordial hospitality.

\section{Appendix i. Motif Sharing Between the West New Britain and Eastern Lapita Assemblages}

a. TONGA (see Poulsen 1987)

Of the fifty Anson motifs identified from Poulsen's Tonga assemblages, half are shared with the West New Britain assemblages under analysis, plus the Far Western assemblages from FCR/FCS, EAQ, and ECA (Table A.1).

Of these twenty-five motifs, only seven were common to all of Anson's style areas (1983). The rest were not, and their presence cannot be seen as the result of a wide corpus of common motifs found in all the assemblages. One was previously found in only Far Western assemblages, three in Far Western/Western assemblages, ten in Western assemblages, and four in Western/Eastern assemblages.

\section{b. NAIGANI (see Kay 1984)}

Of the forty-five Anson motifs identified from Kay's Naigani assemblage, nineteen are shared with the West New Britain assemblages, plus the Far Western assemblages from FCR/FCS, EAQ, and ECA (Table A.2).

Of these nineteen motifs, only four were common to all of Anson's "style areas," three were previously found in Far Western/Western assemblages, ten in Western assemblages, and two in Western/Eastern assemblages. Again the pres- 
Table A.t. Motifs Shared by the Tonga and Bismarck Archipelago Assemblages

\begin{tabular}{lcccccccccc}
\hline POULSEN & ANSON & & FOH & FOH & & & & & FCR/ \\
MOTIF & MOTIF & FNY & Sq. D/E/F & Sq. G & FOJ & FNT & FSZ & EAQ & FCS & ECA \\
\hline B1 & 1 & $\times$ & $\times$ & - & $\times$ & - & $\times$ & $\times$ & $\times$ & - \\
A9 & 16 & - & - & - & - & - & $\times$ & - & - & - \\
B3 & 18 & - & - & - & - & - & - & $\times$ & - & - \\
B5 & 21 & - & - & - & - & - & - & $\times$ & - & - \\
B8 & 35 & $\times$ & $\times$ & $\times$ & - & $\times$ & $\times$ & - & - & - \\
C7 & 37 & - & $\times$ & - & $\times$ & - & - & $\times$ & $\times$ & - \\
C5 & 134 & - & - & - & - & - & $\times$ & - & - & - \\
D8 & 164 & - & $\times$ & - & - & - & - & - & - & - \\
D10 & 168 & $\times$ & - & - & - & - & - & $\times$ & - & - \\
D19 & 207 & $\times$ & - & - & $\times$ & $\times$ & - & $\times$ & - & - \\
D20 & 231 & $\times$ & - & - & - & - & - & - & - & - \\
D24 & 237 & $\times$ & $\times$ & $\times$ & $\times$ & $\times$ & $\times$ & - & - & - \\
E & 260 & - & - & - & - & - & - & $\times$ & $\times$ & - \\
P15 & 324 & - & - & - & $\times$ & - & - & - & - & - \\
P13 & 325 & - & - & - & - & - & $\times$ & - & - & - \\
C1 & 391 & - & $\times$ & - & - & - & $\times$ & - & - & - \\
G2 & 436 & - & - & $\times$ & - & - & - & - & - & - \\
G3 & 438 & - & $\times$ & - & - & - & - & - & - & - \\
F3 & 442 & $\times$ & $\times$ & - & - & - & - & $\times$ & - & - \\
J6 & 444 & $\times$ & $\times$ & - & - & - & - & - & - & - \\
J6 & 445 & $\times$ & $\times$ & - & - & - & - & - & - & - \\
J11 & 448 & - & $\times$ & - & $\times$ & - & - & - & - & - \\
A22 & 495 & - & $\times$ & $\times$ & $\times$ & - & $\times$ & - & - & - \\
A7/8 & 496 & $\times$ & $\times$ & $\times$ & $\times$ & $\times$ & $\times$ & - & - & - \\
A1 & 497 & - & $\times$ & - & - & - & - & - & - & - \\
\hline & & & & & & & & & & \\
\hline
\end{tabular}

ence of the non-common motifs is not due to a wide corpus of common motifs found in all the assemblages.

c. NiUAtoputapu (see Kirch 1988a)

Four of the eight identifiable Anson motifs in the Niuatoputapu assemblage were found in either the West New Britain sites or Anson's Far Western sites (Table A.3).

Of these, Anson's motif 162 was previously found in both Far Western and Western assemblages, motifs 385 and 494 in Western assemblages, and motif 448 in both Western/Eastern assemblages.

d. TIKOPIA (see Kirch and Yen 1982)

In Tikopia site TK-4, only five dentate sherds were found (Kirch and Yen 1982:197). Kirch described the sherd decoration using the Mead system. Anson's motif 494 (DE1.1) and 16 (DE2.2) are found. Kirch mentions motif M15 (combination of DE5 and GZ1, Kirch and Yen 1982, fig. 81g). This could be accommodated by any of Anson's motifs 441-447. Note that the positioning of an assemblage on the presence of only dentate five sherds is tenuous, although both motifs 494 and 16 are found in the West New Britain assemblages (FOH squares $\mathrm{D} / \mathrm{E} / \mathrm{F}$ and FSZ, respectively). 
Table A.2. Motifs Shared by Naigani and the Bismarcks

\begin{tabular}{lccccccccc}
\hline ANSON & & FOH & FOH & & & & & FCR/ \\
MOTIFS & FNY & Sq. D/E/F & Sq. G & FOJ & FNT & FSZ & EAQ & FCS & ECA \\
\hline 31 & $\times$ & - & - & - & - & - & - & - & - \\
37 & - & $\times$ & - & $\times$ & - & - & $\times$ & $\times$ & - \\
133 & - & - & - & - & $\times$ & - & - & - & - \\
162 & - & - & - & - & - & - & $\times$ & - & - \\
207 & $\times$ & - & - & $\times$ & $\times$ & - & $\times$ & - & - \\
230 & $\times$ & - & - & - & - & - & - & - & - \\
231 & $\times$ & - & - & - & - & - & - & - & - \\
236 & - & $\times$ & - & $\times$ & - & - & - & - & - \\
237 & $\times$ & $\times$ & $\times$ & $\times$ & $\times$ & $\times$ & - & $\times$ & - \\
260 & - & - & - & - & - & - & $\times$ & $\times$ & - \\
271 & - & $\times$ & - & - & - & - & - & - & - \\
313 & - & - & - & - & - & - & $\times$ & - & - \\
366 & - & $\times$ & - & $\times$ & - & $\times$ & - & - & - \\
435 & $\times$ & - & - & $\times$ & - & - & - & - & - \\
436 & - & - & $\times$ & - & - & - & - & - & - \\
444 & $\times$ & $\times$ & - & - & - & - & - & - & - \\
448 & - & $\times$ & - & $\times$ & - & - & - & - & - \\
494 & - & $\times$ & - & - & - & - & - & - & - \\
497 & - & $\times$ & - & - & - & - & - & - & - \\
\hline
\end{tabular}

Table A.3. Motifs Shared between Niuatoputapu and the Bismarcks

\begin{tabular}{lcl}
\hline NIUATOPUTAPU MOTIF & ANSON MOTIF & \multicolumn{1}{c}{ SITE } \\
\hline M99.1 & 494 & FOH Sq. D, E, and F \\
M15 & 448 & FOH Sq. D, E, and F \\
& & FOJ \\
M1 & 385 & FNT \\
M16 & 162 & EAQ \\
\hline
\end{tabular}

e. FUTUNA (see Sand 1990)

The dentate assemblage from Asi Pani (SI-001A) on Futuna provided only a few sherds for comparison with other sites, although what is published shows motifs expected for later sites (Sand 1990).

\section{f. MULIFANUA (see Green 1974c)}

The Mulifanua dentate assemblage fits into the pattern demonstrated above. Only thirty-eight dentate sherds are recorded for what Green calls an Early Eastern Lapita assemblage (Green 1974c). Green (1974c:173) cautions against making chronological comparisons with either the Fijian or Tongan assemblages due to "the restricted range of identifiable motifs." Yet from an examination of the published photographs and illustrations, a minimum of eight (Green 1974c, pls. 16 and 17, fig. 71) Anson motifs are present, of which five are also found in the West New Britain assemblages: 
1. Anson motif 1 is found in FSZ, EAQ, FCR/FCS, FOJ, FOH squares D/E/F, and FNY. This motif is one of the "corpus of motifs" common to Far Western, Western, and Eastern assemblages.

2. Anson motif 16 is found in FSZ. This motif has previously been found in Western assemblages only: Watom (Meyer collection) and New Caledonia (Ile des Pins).

3. Anson motif 208 is found in FOH squares D/E/F, FNY, EAQ.

4. Anson motif 435 is found in FNY, FOJ, and FNT. This motif has also been found in the following Western assemblages: Reef/Santa Cruz (RF2; SZ-8); New Caledonia (Site 13).

5. Anson motif 494 is found in $\mathrm{FOH}$ squares $\mathrm{D} / \mathrm{E} / \mathrm{F}$. This motif has also been found in the Western assemblages at the Ile des Pins and Site 13 in New Caledonia.

Of the other three motifs, two are found in the Reef Islands (Anson motif 200, RF6; and 402, RF2) and one in Fiji (Anson motif 250? Yanuca). The point to be made is that most of these shared motifs are not part of the "substantial corpus of early motifs" across the Lapita assemblages (see Green 1979:40).

\section{REFERENCES}

Allen, J.

1984 In search of the Lapita Homeland. Journal of Pacific History 19:186-201.

1991 Introduction, in Report of the Lapita Homeland Project: 1-7, ed. J. Allen and C. Gosden. Occasional Papers in Prehistory 20, Department of Prehistory, Research School of Pacific Studies. Canberra: Australian National University.

Anderson, A., ANd G. Clark

1999 The age of Lapita settlement in Fiji. Archaeology in Oceania 34:31-39.

Anson, D.

1983 Lapita Pottery of the Bismarck Archipelago and its Affinities. Unpublished Ph.D. diss. University of Sydney, Sydney, Australia.

1986 Lapita pottery of the Bismarck Archipelago and its affinities. Archaeology in Oceania 21:157-165.

1987 Reply to Kirch et al. Archaeology in Oceania 22:127-128.

1990 Aspiring to paradise, in Lapita Design, Form and Composition: 53-58, ed. M. Spriggs. Occasional Papers in Prehistory 19, Department of Prehistory, Research School of Pacific Studies. Canberra: Australian National University.

BAXTer, M. J.

1994 Exploratory Multivariate Analysis in Archaeology. Edinburgh: Edinburgh University Press.

Best, S.

1984 Lakeba: The Prehistory of a Fijian Island. Unpublished Ph.D. diss. Department of Anthropology, University of Auckland, Auckland, New Zealand.

BurLey, D. V.

1998 Tongan archaeology and the Tongan past, 2850-150 B.P. Journal of World Prehistory $12: 337-392$.

Burley, D. V., D. E. Nelson, And R. Shutler

1999 A radiocarbon chronology for the eastern Lapita frontier in Tonga. Archaeology in Oceania 34:59-70.

Chatfield, C., and A. J. Collins

1980 Introduction to Multivariate Analysis. London: Chapman and Hall.

Dickinson, W. R., AND R. C. GReEN

1998 Geoarchaeological context of Holocene subsidence at the Ferry Berth Lapita site, Mulifanua, Upolu, Samoa. Geoarchaeology 13:239-263. 
Donovan, L. J.

1973 A study of the decorative system of the Lapita potters in Reef and Santa Cruz Islands. Unpublished M.A. thesis. Department of Anthropology, University of Auckland, Auckland, New Zealand.

GosDen, C.

1989 Prehistoric social landscapes of the Arawe Islands, West New Britain Province, Papua New Guinea. Archaeology in Oceania 24:45-58.

1990 Archaeological work in the Arawe Islands, West New Britain Province, Papua New Guinea, December 1989-February 1990. Australian Archaeology 30:37-44.

1991 Towards an understanding of the regional record from the Arawe Islands, West New Britain, Papua New Guinea, in Report of the Lapita Homeland Project: 205-216, ed. J. Allen and C. Gosden. Occasional Papers in Prehistory 20, Department of Prehistory, Research School of Pacific Studies. Canberra: Australian National University.

Gosden, C., And J. WebB

1994 The creation of a Papua New Guinean landscape: Archaeological and geomorphological evidence. Journal of Field Archaeolog $\gamma 21: 29-51$.

GreEN, R. C.

$1974 a$ A review of the portable artifacts from Western Samoa, in Archaeology in Western Samoa, Vol. 2:245-275, ed. R. C. Green and J. Davidson. Bulletin of the Auckland Institute and Museum 7. Auckland.

$1974 b$ Sites with Lapita pottery: Importing and voyaging. Mankind 9:253-259.

1974c Pottery from the Lagoon at Mulifanua, Upolu, in Archaeology in Western Samoa, Vol. 2:170-175, ed. R. C. Green and J. Davidson. Bulletin of the Auckland Institute and Museum 7. Auckland.

1976 Lapita sites in the Santa Cruz group, in Southeast Solomon Islands Cultural History: 245265, ed. R. C. Green and M. Cresswell. Wellington: The Royal Society of New Zealand Bulletin 11.

1978 New Sites with Lapita Pottery and Their Implications for an Understanding of the Settlement of the Western Pacific. Working Papers in Anthropology, Archaeology, Linguistics and Maori Studies 51. Auckland: Department of Anthropology, University of Auckland.

1979 Lapita, in The Prehistory of Polynesia: 27-60, ed. J. Jennings. Canberra: Australian National University Press.

1990 Lapita design analysis: The Mead system and its use: A potted history, in Lapita Design, Form and Composition: 33-52, ed. M. Spriggs. Occasional Papers in Prehistory 19. Department of Prehistory, Research School of Pacific Studies. Canberra: Australian National University.

1991a The Lapita cultural complex: Current evidence and proposed models. Bulletin of the IndoPacific Prehistory Association 11:295-305.

19916 A reappraisal of the dating for some Lapita sites in the Reef/Santa Cruz group of the Southeast Solomons. The Journal of the Polynesian Society 100:197-207.

Green, R. C., AND P. V. KirCH

1997 Lapita exchange systems and their Polynesian transformations: Seeking explanatory models, in Prehistoric Long-Distance Interaction in Oceania: An Interdisciplinary Approach: 1937, ed. M. Weisler. New Zealand Archaeological Association Monograph 21. Auckland: Auckland Museum.

IRwIN, G. J.

1992 The Prehistoric Exploration and Colonisation of the Pacific. Cambridge: Cambridge University Press.

Jennings, J., R. Holmer, J. Janetska, and H. Smith

1976 Excavations on Upolu, Western Samoa. Pacific Anthropological Records 25.

JENNINGS, J., AND R. Holmer, EDS.

1980 Archaeological Excavations in Western Samoa. Pacific Anthropological Records 32.

KAY, R.M.A.

1984 Analysis of Archaeological material from Naigani. Unpublished M.A. thesis. Department of Anthropology, University of Auckland, Auckland, New Zealand.

KENNEDY, J.

1983 On the significance of Western Melanesia: The significance of new data from the Admiralties. Australian Archaeology 16:115-122.

KIRCH, P. V.

1976 Ethno-archaeological investigations in Futuna and Uvea (Western Polynesia): A preliminary report. Journal of the Polynesian Society 85:27-69. 
1981 Lapitoid settlements of Futuna and Alofi, Western Polynesia. Archaeology in Oceania $16: 127-143$.

1988a Niuatoputapu: The prehistory of a Polynesian Chiefdom. Thomas Burke Memorial, Washington State Museum Research Report No. 5. Seattle: Burke Museum.

$1988 \mathrm{~b}$ Long-distance exchange and island colonization: The Lapita case. Norwegian Archaeological Review $21: 103-117$.

1997 Lapita Peoples: Ancestors of the Oceanic World. Oxford: Blackwell.

Kirch, P. V., M. S. Allen, V. L. Butler, and T. L. Hunt

1987 Is there an early Far Western Lapita province? Sample size effects and new evidence from Eloaua Island. Archaeology in Oceania 22:123-127.

KIRCH, P. V., AND T. HunT

1988 Archaeology of the Lapita cultural complex: A critical review. Thomas Burke Memorial, Washington State Museum Research Report No. 5. Seattle: Burke Museum.

KirCH, P. V., AND D. E. YeN

1982 Tikopia: The Prehistory and Ecology of a Polynesian Outlier. Bishop Museum Bulletin 238. Honolulu: Bishop Museum Press.

MeAd, S., L. Birks, H. Birks, E. Shaw

1975 The Lapita pottery style of Fiji and its associations. Polynesian Society Memoir 38:1-98.

PARKER, M.

1981 Vessel forms of the Reef Island SE-RF-2 site and their relationship to vessel forms in other Western Lapita sites of the Reef/Santa Cruz and Island Melanesian area. Unpublished M.A. thesis. Department of Anthropology, University of Auckland, Auckland, New Zealand.

Pawley, A., and R. Green

1973 Dating the dispersal of the Oceanic languages. Oceanic Linguistics 12:1-67.

Poulsen, J.

1987 Early Tongan Prehistory: The Lapita Period on Tongatapu and its Relationships. Terra Australis 12. Department of Prehistory, Research School of Pacific Studies. Canberra: Australian National University.

SAND, C.

1990 The ceramic chronology of Futuna and Alofi: An overview, in Lapita Design, Form and Composition: 123-133, ed. M. Spriggs. Occasional Papers in Prehistory 19, Department of Prehistory, Research School of Pacific Studies. Canberra: Australian National University.

1996 Recent developments in the study of New Caledonia's prehistory. Archaeology in Oceania $31: 45-71$.

1997 The chronology of Lapita ware in New Caledonia. Antiquity 71:539-547.

Shutler, R., D. V. Burley, W. R. Dickinson, E. Nelson, and A. K. Carlson

1994 Early Lapita sites, the colonisation of Tonga and recent data from northern Ha'apai. Archaeology in Oceania 29:53-68.

SPECHT, J.

1988 A Far Western Lapita? Paper presented to the Lapita Design Conference, Department of Prehistory, Research School of Pacific Studies, Australian National University.

1991 Kreslo: A Lapita pottery site in southwest New Britain, Papua New Guinea, in Report of the Lapita Homeland Project: 189-204, ed. J. Allen and C. Gosden. Occasional Papers in Prehistory 20, Department of Prehistory, Research School of Pacific Studies. Canberra: Australian National University.

SPecht, J., AND C. Gosden

1997 Dating Lapita pottery in the Bismarck Archipelago, Papua New Guinea. Asian Perspectives $36: 175-189$.

SPRIGGS, M.

1989 The dating of the Island Neolithic: An attempt at chronometric hygiene and linguistic correlation. Antiquity 63:587-613.

1992 What happens to Lapita in Melanesia? in Poterie Lapita et Peuplement: 219-230, ed. J. C. Galipaud. Noumea: ORSTOM.

1995 The Lapita culture and Austronesian prehistory in Oceania, in The Austronesians: Historical and Comparative Perspectives: 112-133, ed. P. Bellwood, J. Fox, and D. Tryon. Department of Anthropology, Research School of Pacific and Asian Studies. Canberra: Australian National University. 
1996 Chronology and colonisation in island Southeast Asia and the Pacific: New data and an evaluation, in Oceanic Culture History: Essays in Honour of Roger Green: 33-50, ed. J. Davidson, G. Irwin, F. Leach, A. Pawley, and D. Brown. New Zealand Journal of Archaeology Special Publication.

1997 The Island Melanesians. Oxford: Blackwell.

SuMmerhayes, G. R.

2000a Lapita Interaction. Terra Australis 15. Department of Archaeology and Natural History and the Centre of Archaeological Research. Canberra: Australian National University.

20006 What's in a pot? in Australian Archaeologist: Collected Papers in Honour of Jim Allen: 291307, ed. A. J. Anderson and T. Murray. Coombs Academic Publishing. Canberra: Australian National University.

TORRENCE, R.

1993 Archaeological research on Garua Island, West New Britain Province, PNG. Ms.

ToRrence, R., AND J. WebB

1992 Report on archaeological research on Garua Island, West New Britain Province, PNG. Ms.

White, J. P., AND J. Allen

1980 Melanesian prehistory: Some recent advances. Science 207:728-734.

WRIGHT, R.V.S.

1991 Doing Multivariate Archaeology and Prehistory. Department of Anthropology, University of Sydney. Computer software.

\begin{abstract}
Lapita assemblages from the western Pacific have been regionalized into stylistic boundaries or provinces, known as Far Western, Western, and Eastern, and it has been thought that differences between them are partly temporal (Far Western) and mainly a result of isolation after the initial colonization of the area (Western versus Eastern). This paper assesses these constructions by comparing dentate decorated Lapita pottery from assemblages in West New Britain, Papua New Guinea, with assemblages further afield. It is argued here that differences between these style provinces are primarily due to temporal factors and that the terms Far Western, Western, and Eastern should be replaced by Early, Middle, and Late Lapita. KeYwords: Lapita, West New Britain, Melanesian archaeology, pottery.
\end{abstract}

